\title{
Causative Factors Involved in Development of Resistance to Tyrosine Kinase Inhibition and Novel Strategies Designed to Override This Resistance
}

\author{
Ellen Weisberg and James D. Griffin \\ Dana Farber Cancer Institute \\ USA
}

\section{Introduction}

This article describes original work performed in our laboratory related to the characterization of kinase inhibitors developed to treat myeloid leukemia, as well as identified mechanisms that likely contribute to resistance to kinase inhibition. Specifically, we provide detailed overviews of the kinase inhibitors nilotinib, used in the treatment of chronic myeloid leukemia (CML) and midostaurin, which is currently under investigation in late stage clinical trials for the treatment of mutant FLT3-positive acute myeloid leukemia (AML). Presented as well is a description of studies investigating strategies that leukemic cells employ to escape killing through kinase inhibition, including alterations in the expression and composition of targeted proteins and chemoresistance conferred by the bone marrow microenvironment. We provide a general overview of kinase inhibitors in preclinical and clinical development for CML and AML, and also discuss the use of combination therapy as an approach to enhancing the efficacy of tyrosine kinase inhibition and reducing the incidence of residual disease.

\section{Development of BCR-ABL inhibitors and combination therapy studies geared toward overriding resistance to BCR-ABL inhibition}

\section{Imatinib resistance: Introduction}

The development of resistance in leukemia patients to treatment with targeted tyrosine kinase inhibitors is a growing area of concern. For instance, the ABL inhibitor imatinib (STI571) (Druker et al., 1996; Buchdunger et al., 2001), which also inhibits KIT and plateletderived growth factor receptor (PDGFR), has proven to be a highly effective, front line therapy for CML, a hematopoietic malignancy caused by the product of a reciprocal $t(9 ; 22)$ chromosomal translocation, $B C R-A B L$ (Deininger et al., 2000). This targeted therapy has changed how newly diagnosed CML patients are treated and has substantially improved their prognosis. However, patients in the more advance phases of CML (namely, accelerated or blast crisis phase CML patients) often relapse due to drug resistance resulting from the emergence of imatinib-resistant point mutations within the BCR-ABL tyrosine kinase 
domain that reduce sensitivity towards imatinib (Gorre et al., 2001) or amplification of the target gene (Weisberg and Griffin, 2000).

Imatinib resistance and disease relapse in some patients can also be due to BCR-ABLindependent mechanisms, as exemplified by the small residual pool of BCR-ABL-positive quiescent leukemic stem cells existing in CML patients that have achieved complete responses after imatinib treatment. This inability of imatinib to completely eradicate quiescent leukaemic stem cells occurs despite the high expression of BCR-ABL mRNA and protein in these cells (Michor et al., 2005; Roeder et al., 2006; Copland et al., 2006), which suggests that these leukemic stem cells are not dependent on BCR-ABL for viability. Therefore, a population of BCR-ABL-positive, quiescent stem cells continues to exist after imatinib therapy even in patients who have achieved complete responses, and the insensitivity of these cells to imatinib is believed to contribute to relapse observed in some patients following termination of imatinib treatment. The existence of this quiescent cell population is important to consider when attempting development of effective therapies for overriding intrinsic kinase inhibitor resistance and resistance due to stromal-mediated mechanisms. Such novel treatment approaches must be able to eradicate this cell population if maximum clinical benefit and complete disease-free survival is to be achieved.

Among strategies to override imatinib resistance are the direct targeting of the BCR-ABL protein and the targeting of mediators of signaling pathways downstream of BCR-ABL that are needed for transformation. Biorational drug design has led to the development of novel agents that overcome some forms of imatinib resistance, and impressive results obtained in clinical trials have led to rapid FDA approval of second generation compounds that are presently used to treat newly diagnosed CML patients.

$B C R-A B L$ point mutations as a mechanism of imatinib resistance

Although early studies based on cell line models pointed toward $B C R-A B L$ gene amplification and over-expression of BCR-ABL mRNA and protein as contributing to imatinib resistance (Weisberg and Griffin, 2000; Mahon et al., 2000; le Coutre et al., 2000), the most common mechanism of imatinib resistance was later discovered to be point mutations in the $B C R-A B L$ gene that lead to changes in amino acids in the BCR-ABL protein catalytic domain. Of the mechanisms considered to be of major importance in the development of drug resistance, gene amplification accounts for approximately $10 \%$ of relapse in patients, whereas mutations in the kinase domain account for $40-90 \%$ of relapse in patients. Other important mechanisms include mutations or activation of other genes (i.e. Lyn) (Wu et al., 2008) and the contribution of organic cation transporter 1 or other related drug pumps (Engler et al., 2010). Mechanisms of minor importance or uncertain significance include the influence of multidrug resistance 1 gene (Gambacorti-Passerini et al., 2000) and alpha1 acidic glycoprotein (Mahon et al., 2000).

BCR-ABL point mutations, which diminish the binding of imatinib to its target, are often those that directly or indirectly impair the binding of imatinib to the BCR-ABL protein without compromising the function of the ABL tyrosine kinase domain. Point mutations that reduce imatinib binding through a direct mechanism are generally positioned around the imatinib binding site, and diminish imatinib binding through alterations in amino acid side chains or topographical changes that sterically hinder the binding of imatinib. Phe317 and Thr315 are examples of this type of BCR-ABL point mutation (Cowan-Jacob et al., 2004). Point mutations that reduce imatinib binding through an indirect mechanism utilize the distinct binding mode of a drug to BCR-ABL. Generally, there are three primary kinase 
inhibitor binding modes that represent main mechanisms for pharmacological inhibition of kinase activity (Liu and Gray et al., 2006):

1. Kinase inhibitor directly competes with ATP in the ATP binding site. Inhibitors of this type are known as "Type I" and bind to the "Asp-Phe-Gly (DFG)-in" conformation (the "DFG" motif is highly conserved in protein kinases and sits near the beginning, or Nterminus, of the activation loop) .

2. Kinase inhibitor engages an adjacent allosteric binding site, typically accessible when the activation loop and/or alpha-c helix is folded away from the binding site, which leads to kinase inactivation. Inhibitors of this type are known as "Type II" and bind to the "DFG-out" conformation.

3. Kinase inhibitor binds at sites distal from the ATP binding site.

Imatinib, a "Type II" inhibitor, binds to the catalytically inactive conformation of the ABL kinase domain. BCR-ABL point mutations that destabilize the inactive conformations of the DFG motif diminish the binding capacity of imatinib, and therefore work through an indirect mechanism.

Over fifty different BCR-ABL point mutations have been identified (Rourmiantsev et al., 2002; Von Bubnoff et al., 2002; Shah et al., 2002; Hochhaus et al., 2002) and generally fall into different categorical regions that include the hinge region (which bridges the $\mathrm{C}$ - and $\mathrm{N}$ terminal lobes of the kinase domain to develop the ATP-binding cleft), A-loop, and P-loop (or "nucleotide-binding loop"). The position of the A-loop, which includes amino acids 381402, regulates ABL kinase activity. Mutations in the A-loop typically confer moderate resistance. In contrast, P-loop mutations, which occur at the binding site for phosphates of ATP, include amino acids 244-255 of ABL, are highly imatinib-resistant, and confer a worse prognosis than other mutations (Soverini et al., 2005). Point mutations in the ABL kinase domain that destabilize the inactive conformations of the P-loop increase the free energy of the imatinib-ABL drug-protein complex, and in effect diminish imatinib binding. Gly250, Tyr 253, and Glu255 in the P-loop are examples of mutations that reduce imatinib binding through an indirect mechanism.

The vast majority of the BCR-ABL point mutations identified occur infrequently. Mutations such as those occurring at residues Thr315, Phe359, Met351, Gly250, Glu255, and Tyr253 comprise up to $70 \%$ of all existing mutations. It is possible that extremely rare levels of BCR$\mathrm{ABL}$ point mutations pre-exist treatment with imatinib and increase in frequency during imatinib therapy (Roche-Lestienne et al., 2002; Hofmann et al., 2003).

In addition to detection of BCR-ABL point mutations in patients, BCR-ABL point mutations characterized as conferring imatinib resistance have been identified through in vitro random mutagenesis of BCR-ABL (Shah et al., 2002; Hochhaus et al., 2002). Some identified mutations were found to exist distal to the kinase domain, including the Src homology 2 (SH2) and SH3 domains and N-terminal cap region (Hochhaus et al., 2002; Azam et al., 2003; Pluk et al., 2002).

The detection of a point mutation in the BCR-ABL kinase domain was first reported in imatinib-resistant CML patients: three out of nine patients were characterized by $B C R-A B L$ gene amplification, while six out of nine patients were characterized by an isoleucine substitution in the Thr315 residue located at the periphery of the nucleotide-binding site of ABL (also referred to as the "gatekeeper position") (Gorre et al., 2001). The Thr315 residue, located in the hinge region, participates through a hydroxymethylene side chain in a critical $\mathrm{H}$-bond interaction between imatinib and its protein target (Schindler et al., 2000; Manley et al., 2002; Nagar et al., 2002). Mutation of threonine to isoleucine confers resistance to 
imatinib because of direct steric intrusion of the bulky isoleucine side chain, as well as loss of the hydrogen-bonding interaction in the ATP-cleft. An independent study of the crystal structure of an imatinib analog bound to ABL had shown Thr315 to be critical for the binding of imatinib to $\mathrm{ABL}$, and the mutation of threonine to valine at this residue (T315V) was observed to confer imatinib resistance (Schindler et al., 2000; Corbin et al., 2002).

Development of second generation BCR-ABL inhibitors designed to override imatinib resistance

Nilotinib

As an approach to overriding imatinib resistance, we characterized and developed the phenylaminopyrimidine-based Type II ATP competitive inhibitor, nilotinib (NVPAMN107-NX; 4-methyl-N-[3-(4-methyl-1H-imidazol-1-yl)-5-(trifluoromethyl)phenyl]-3-[[43-pyridinyl)-2-pyrimidinyl]amino]benzamide), based on the crystal structures of inhibitors complexed with ABL (Cowan-Jacob et al., 2004). As with imatinib, another Type II ATP competitive inhibitor, part of nilotinib's structure binds the ATP binding site, while part of its structure binds adjacent to the ATP binding site. Nilotinib was designed to fit into the ATP-binding site of BCR-ABL with higher affinity than imatinib, and demonstrates significantly higher potency than imatinib in inducing apoptosis of BCR-ABL-expressing cells (IC50 $\leq 10 \mathrm{nM}$ ) by directly inhibiting ABL tyrosine kinase (Weisberg et al., 2005). Nilotinib also shows activity against a panel of imatinib-resistant BCR-ABL mutants, with the exception of T315I, and is effective in preventing the onset of leukemia in a BCR-ABL+ leukemic mouse model, and in prolonging the survival of mice harboring imatinib-resistant BCR-ABL-expressing cells (Weisberg et al., 2005; O'Hare et al., 2005). Crystallographic analysis of nilotinib complexed with ABL shows that, like imatinib, nilotinib binds to the inactive conformation of ABL. This suggests that the superior topographical fit to the ABL protein, as well as differences in the binding nature of nilotinib to $\mathrm{ABL}$, contribute to the higher potency of nilotinib versus imatinib.

Clinical trial results with nilotinib in imatinib-resistant patients were favorable (Kantarjian et al., 2006; le Coutre et al., 2006; Ottmann et al., 2006). A phase III randomized, open-label multicenter study was conducted as a direct comparison of imatinib and nilotinib in CML patients. Results showed nilotinib to be superior to imatinib in patients with newly diagnosed chronic phase CML (Saglio et al., 2010). On October 29, 2007, the FDA granted accelerated approval to nilotinib for use in the treatment of chronic phase and accelerated phase Philadelphia chromosome positive $(\mathrm{Ph}+) \mathrm{CML}$ in adult patients resistant or intolerant to prior therapy that included imatinib. On June 17, 2010, the FDA granted accelerated approval to nilotinib for treatment of adult patients with newly diagnosed $\mathrm{Ph}+\mathrm{CML}$ in chronic phase.

\section{Dasatinib}

Dasatinib (BMS-354825) is a second generation Type I ATP competitive inhibitor of BCRABL that is both a potent ABL inhibitor and a potent Src family kinase inhibitor (Shah et al., 2004; O'Hare et al., 2005; Burgess et al., 2005; Das et al, 2006; Melnick et al., 2006). Overexpression and activation of Src family kinases, such as LYN and HCK, have been shown to be associated with imatinib resistance (Donato et al., 2003), which suggests that the simultaneous targeting of BCR-ABL and Src family kinases may be effective in overriding resistance to imatinib. Unlike imatinib and nilotinib, which bind to the inactive conformation of BCR-ABL, dasatinib binds to the active conformation (Tokarski et al., 2006). Similar to nilotinib, dasatinib is effective against a number of imatinib-resistant BCR-ABL 
point mutants, with the notable exception of the T315I gatekeeper mutant (Shah et al., 2004; O’Hare et al., 2005; Burgess et al., 2005).

Dasatinib received accelerated approval by the FDA in June 2006 and the European Medicines Agency (EMEA) in November 2006 for treatment of adults in all phase of CML with resistance or intolerance to imatinib treatment. This approval was based on positive results in early (Phase I and II) clinical trials (Talpaz et al., 2006; Cortes et al., 2007). Dasatinib was also approved for treatment of drug-resistant $\mathrm{Ph}+$ acute lymphoblastic leukemia (ALL) patients, in which a $190 \mathrm{kDa} B C R-A B L$ protein is expressed resulting from an alternative breakpoint in the $B C R$ gene. As with nilotinib, dasatinib has been granted FDA approval for therapy of newly diagnosed CML patients (Kantarjian et al, 2010).

\section{Other BCR-ABL inhibitors}

Dual ABL and Src inhibitors, bosutinib (SKI-606) (Puttini et al., 2006; Golas et al., 2003), which is a Type I ATP competitive inhibitor that only occupies the region normally occupied by ATP, and INNO-406 (first developed as NS-187) (Kimura et al., 2005), are active against a panel of imatinib-resistant BCR-ABL point mutants with the exception of the T315I gatekeeper mutant. AZD0530 is another dual ABL and Src inhibitor and Type I ATP competitive inhibitor that only weakly inhibits BCR-ABL (Lockton et al., 2005; Hennequin et al., 2006).

Aurora kinase inhibitors, which work through inhibition of the Aurora family of serine/threonine kinases, members of which are important for mitotic progression, represent another class of second generation inhibitors of BCR-ABL. Examples include PHA-739358 (Nerviano Medical Sciences) (Fancelli et al., 2006), which has been tested in early clinical trials in patients that relapsed after treatment with imatinib. PHA-739358 is a Type I inhibitor that binds the ATP binding site directly. Another example of an Aurora kinase inhibitor is MK-0457 (first developed as VX-680), which inhibits the proliferation of cells expressing the T315I-BCR-ABL gatekeeper mutant at submicromolar concentrations (Carter et al., 2005). MK-0457 has shown activity in some patients harboring the T315I mutation (Giles et al., 2007).

Non-ATP-competitive BCR-ABL inhibitors represent another class of second generation BCR-ABL inhibitors that work either via a non-ATP competitive allosteric mechanism or by prevention of substrate binding. Examples include ON012380, which shows potent activity against BCR-ABL-positive cells (Gumireddy et al., 2005). Compounds of this class make a covalent bond to the kinase and act as irreversible inhibitors. One complication is the fact that these compounds bind the substrate binding sites of multiple kinases, and therefore are very cytotoxic. Consequently, no clinical compound has been derived from this series. NonATP competitive inhibitors are also exemplified by the GNF2 and GNF5 family of inhibitors, which bind to the myristate binding site of BCR-ABL and inhibit its activity by stabilizing a catalytically less competent conformation of the protein (Adrian et al., 2006; Zhang et al., 2010). In addition, a type II inhibitor, GNF-7, has been shown to inhibit the T315I mutant in vitro and in vivo (Choi et al., 2010).

As an approach to overriding imatinib resistance, we developed and characterized HG-7-8501, which is a Type II ATP competitive inhibitor that opens up a new chemical space in the field of kinase inhibitor development (Weisberg et al., 2010a). The structural inspiration for HG-7-85-01 is an amalgam of dasatinib and nilotinib, and is mostly utilization of the Type II nilotinib binding mode. Part of the structure of HG-7-85-01 binds to the ATP binding site, while the other part of its structure binds adjacent to the ATP binding site. In addition to 
inhibiting T315I-BCR-ABL in CML, HG-7-85-01 was observed to inhibit gatekeeper mutants of multiple kinases of therapeutic interest including T670I c-Kit and T674I-PDGFRalpha, which are clinically observed in gastrointestinal stromal tumor (GIST) and hypereosinophilic syndrome (HEL). Despite this broad profile with respect to 'gatekeeper' mutant kinases, HG-7-85-01 is not a promiscuous inhibitor, and no other inhibitor has been reported to possess this biological profile. Demonstration that this multi-gatekeeper mutant profile can be achieved is very important to the field because many pharmaceutical companies are reluctant to develop inhibitors for drug-resistant mutant kinases as they do not believe a sufficient number of patients are likely to benefit. The biological profile of HG7-85-01 demonstrates that a single compound could be developed that is capable of simultaneously targeting drug-resistant target kinases relevant across a range of malignancies.

Progress is being made toward development of pan-BCR-ABL inhibitors that target all identified BCR-ABL point mutants, including T315I-BCR-ABL gatekeeper mutation (the socalled "third generation" of BCR-ABL inhibitors). However, as the potential for emergence of new drug-resistant BCR-ABL point mutations still exists, benefit is likely to be gained from further development of BCR-ABL inhibitors displaying higher potency and distinct mutagenicity profiles, as well as therapeutic approaches involving administration of more than one BCR-ABL inhibitor or combined use of signal transduction inhibitors and BCRABL inhibitors.

\section{Combination therapy as an approach to overriding resistance to $B C R-A B L$ inhibition}

As it was anticipated that, similar to imatinib, resistance to nilotinib and dasatinib would likely also emerge due to arising BCR-ABL point mutations in CML and Ph+ ALL, mutagenesis screens were performed to identify nilotinib- and dasatinib-resistant BCR-ABL point mutations and showed overlapping but distinct mutagenicity profiles (Von Bubnoff et al., 2006; Bradeen et al., 2006; Ray et al., 2007). There has been substantial interest in testing the notion that simultaneous or sequential administration of more than one ABL inhibitor might delay the onset of emergence of drug-resistant BCR-ABL point mutations. For instance, we have shown beneficial paired combinations of imatinib and nilotinib against imatinib-resistant CML (Weisberg et al., 2007a). Specifically, we demonstrate the synergistic interaction between nilotinib and imatinib against both non-mutated BCR-ABL and imatinib-resistant BCR-ABL point mutants. It has been suggested that the differential uptake mechanisms for imatinib and nilotinib may contribute to the observed synergy between the two agents (White et al., 2006). Alternatively, synergy may be explained by the ability of imatinib to increase the intracellular uptake and retention of nilotinib (and therefore its overall concentration), possibly through imatinib inhibition of ABCB1-mediated efflux of nilotinib (White et al., 2007). The demonstrated synergy between imatinib and nilotinib complements other published reports showing synergistic interaction between imatinib and the dual Src/Abl inhibitors, dasatinib and AP23848 (O'Hare et al., 2005), as well as synergistic interactions between imatinib and a panel of standard chemotherapeutic agents (Liu et al., 2002). In addition, combinations of dasatinib and imatinib have proven to be effective in diminishing the frequency of occurrence of drug-resistant BCR-ABL mutants, with the exception of T315I (Shah et al., 2004; Burgess et al., 2005; Bradeen et al., 2006; Talpaz et al., 2006). As improvement of disease-free survival could potentially be achieved from combination therapy involving inhibitors from the same or diverse structural classes, these studies could serve as a guide for further clinical investigation. 
Since clonal resistance could potentially be overcome by combining two agents with different resistance profiles, we investigated the ability of HG-7-85-01 to positively combine with GNF-5, which is unable to potently inhibit T315I as a single agent (Zhang et al., 2010; Weisberg et al., 2010c). We demonstrated that combinations of HG-7-85-01 with GNF-5 have at least additive effects against both non-mutated BCR-ABL and BCR-ABL T315I in vitro and in vivo (Weisberg et al., 2010c). GNF-5 was also shown to enhance the activity of nilotinib against both non-mutated BCR-ABL and T315I-BCR-ABL in vitro and in vivo (Zhang et al., 2010).

An important characteristic of leukemia that confers survival advantages is the common deregulation of one or more of the three signaling pathways: PI3K/PTEN/Akt/mTOR, RAS/Raf/MEK/ERK, and Jak/STAT, each frequently activated by mutations in upstream genes. The redundancy and simultaneous/cross-activation between the three pathways warrants consideration of the use of a multi-targeted therapeutic strategy, or the use of more than one type of signaling inhibitor. We have shown that the dual PI3K/PDK-1 inhibitor, BAG956, has the ability to enhance the inhibitory effects of imatinib and nilotinib, respectively, to effectively kill BCR-ABL-expressing cells both in vitro and in vivo (Weisberg et al., 2008a). Similarly, enhanced apoptosis of BCR-ABL-positive cells has been found to result from treatment with a STAT5 inhibitor and imatinib or nilotinib (Nelson et al., 2011). In addition, inhibitors of MAPK and PI3K/Akt signaling have been implicated in upregulation of proapoptotic BIM expression (Strasser et al., 2005). This is of potential importance with respect to imatinib resistance, as the proapoptotic BH3 domain-only protein, BIM, as well as proapoptotic BAD, mediate imatinib-induced apoptosis (Kuroda et al., 2006). Of relevance, the BH3 mimetic, ABT-737, overrides imatinib resistance due to loss of BIM and BAD (Kuroda et al., 2006). Inhibition of PI3K/Akt signaling also may be of potential benefit insofar as stromal-mediated chemoresistance is concerned, as Akt has been shown to be involved in leukemic cell survival in the bone marrow microenvironment (Tabe et al., 2007).

\section{Development of inhibitors of FLT3, and combination therapy studies geared toward overriding resistance to FLT3 inhibition}

Mutant FLT3 as a therapeutic target for AML

The hematological malignancy, AML, is generally characterized by a block in cellular differentiation at different stages and aberrant proliferation of myeloid precursor cells. Early models have indicated that two types of mutations are responsible for the development of AML: One type of mutation is responsible for blocking terminal differentiation and the other type of mutation is responsible for promotion of growth and viability. However, full genome sequencing results suggest that up to 20 different mutations initiate AML, and disease development is thus likely more complicated than what the two mutation model proposes.

Approximately $30 \%$ of AML patients, as well as a portion of ALL patients, express a mutated form of the class III receptor tyrosine kinase, FLT3 (Fms-Like Tyrosine kinase-3; STK-1, human Stem Cell Tyrosine Kinase-1; FLK-2, Fetal Liver Kinase-2) (Stirewalt and Radich, 2003). The existence of a FLT3 mutation generally translates into a poorer prognosis in terms of overall survival and disease-free survival (Mattison et al., 2007). The fact that FLT3 mutations are only found in a portion of AML cells suggests that FLT3 mutations may be involved in promotion of disease rather than initiation of disease. 
The most prevalent form of constitutively activated FLT3, found in approximately $20-25 \%$ of AML patients (although in less than $5 \%$ of myelodysplastic syndrome patients), occurs as internal tandem duplications (ITDs) that are located within the juxtamembrane domain (Nakao et al., 1996; Horiike et al., 1997; Kiyoi et al., 1998; Kondo et al., 1999; Rombouts et al., 2000). This mutation has been shown to cause a rapidly lethal myeloproliferative disorder in mice in the absence of a block in differentiation, suggesting that its main role may be to cause hyper-proliferation of primitive myeloid cells (Kelly et al., 2002a). Mutant FLT3 is believed to interact with additional oncogenes that block differentiation, such as AML1/ETO (t(8;21)) PML/RARalpha (t(15;17).) to cause full leukemia development.

Occurring in approximately $7 \%$ of AML cases are gain-of-function FLT3 kinase domain point mutations, frequently at position 835 (Yamamoto et al., 2001). Also identified have been other kinase domain point mutations, including Y842C (Kindler et al., 2005) and N841I (Jiang et al., 2004). An activating point mutation with comparatively weaker transforming potential has also been discovered in a stretch of the FLT3 juxtamembrane domain (Reindl et al., 2006).

\section{Inhibitors of mutant FLT3}

There are several FLT3 inhibitors presently in clinical trials, and a number of novel agents under preclinical investigation. Unfortunately, the FLT3 inhibitors tested thus far clinically induce only partial and transient responses in patients- at best- when used as single agents.

We identified and developed a small molecule inhibitor, the $N$-indolo-carbazole midostaurin (PKC412; N-benzoylstaurosporin), (Weisberg et al., 2002), a broad-spectrum first generation inhibitor that targets constitutively activated mutant FLT3. Other targets of midostaurin include (PDGFRbeta), c-KIT and c-FMS (Weisberg et al., 2002). Midostaurin showed high potency against mutant FLT3 as a target in vitro, and progressive leukemia was prevented in mice transplanted with marrow transduced with a FLT3-ITD-expressing retrovirus (Weisberg et al., 2002).

In early clinical trials, midostaurin administered in sequential and simultaneous combinations with standard chemotherapeutic agents such as daunorubicin and cytarabine induction and high-dose cytarabine consolidation yielded clinical responses with transient and/or reversible side effects (Stone et al., 2004). Midostaurin is one of several FLT3 inhibitors presently undergoing clinical testing, and it is currently under investigation in late stage clinical trials for AML.

We have demonstrated the activity of midostaurin against imatinib-resistant GIST (Weisberg et al., 2006). Specifically, we demonstrated the potent activity of midostaurin against cells expressing two PDGFRalpha mutants associated GIST: the V561D juxtamembrane domain mutation and the less imatinib-sensitive D842V kinase domain mutation. We also demonstrated the ability of nilotinib to positively combine with either imatinib or midostaurin against cells expressing the D842V-PDGFRalpha mutant. Findings reported introduce midostaurin as a potential treatment option for mutant PDGFRalphapositive GIST and warrant its clinical testing for this disease target.

Additional multi-targeted inhibitors, such as dasatinib and the biaryl urea compound and first-generation inhibitor, sorafenib (BAY 43-9006), have been shown to have activity against mutant FLT3 and are under clinical investigation for AML (Auclair et al., 2007; Kancha et al., 2007; Lierman et al., 2007; Zhang et al., 2008; Metzelder et al., 2009; Guerrouahen et al., 2010). Other FLT3 inhibitors that have been clinically investigated and which elicited transient responses in early phase trials include the indolocarbazole alkaloid and first- 
generation inhibitor, CEP-701 (lestaurtinib) (Levis et al., 2002; Smith et al., 2004; Knapper et al., 2006), KW-2449 (Pratz and Levis, 2008; Pratz et al., 2009; Shiotsu et al., 2009), 3substituted indolinones SU5416 (Semaxanib) and SU5614 (Yee et al., 2002; Fielder et al., 2003; Giles et al., 2003; O'Farrell et al., 2004), the indolinone derivative and first-generation inhibitor, SU11248 (SU011248, sunitinib) (Fielder et al., 2005; Kancha et al., 2007; O'Farrell et al., 2003a,b), and the piperazinyl quinazoline and first-generation inhibitor, MLN518 (tandutinib; CT53518) (Kelly et al., 2002b; Cheng and Paz, 2008). Among FLT3 inhibitors in early development are the $N$-(4-(3-amino-1H-indazol-4yl)phenyl-N1(2-fluoro-5methylphenyl) urea ABT-869 (Albert et al., 2006; Shankar et al., 2007; Zhou et al., 2008), the benzimidalzole-quinoline CHIR-258 (TKI258) (Lopes de Menezes et al., 2005), the hydroxystyryl-acrylonitrile LS104 (Kasper et al., 2008) and AP24534 (Gozgit et al., 2011).

AC220 (Chao et al., 2009; Zarrinkar et al., 2009) is a second-generation FLT3 inhibitor that exhibits significantly higher potency and selectivity than first-generation inhibitors, and is under clinical investigation for mutant FLT3-expressing AML and wild-type FLT3harboring AML. A study by Pratz and colleagues suggested, however, that the potency and selectivity of agents targeting mutant FLT3 may not, in fact, be the best predictor of clinical efficacy (Pratz et al., 2010). In their study, AC220 was found to be the most potent inhibitor of several common FLT3 inhibitors tested (including lestaurtinib, midostaurin, sorafenib, and sunitinib) and had the highest index of selectivity. However, lestaurtinib- which had the lowest index of selectivity- was found to be the most effective when tested against FLT3ITD-positive patient samples. Results shown in this study suggested that inhibition of FLT3 autophosphorylation in a FLT3-ITD specimen does not always induce death. For example, a side-by-side comparison of AC220 and lestaurtinib showed that while both compounds fully inhibited FLT3 autophosphorylation and suppressed downstream STAT5 activation in one patient sample, only lestaurtinib induced apoptosis. Relapsed AML samples were observed to be more sensitive to FLT3 inhibition than diagnostic AML, suggesting that some FLT3-ITD AML (i.e. diagnostic) may not be addicted to FLT3 signaling. This study suggested that more selective inhibitors, like AC220 may be less effective in the diagnostic setting while less selective inhibitors- like lestaurtinib or midostaurin- may be more effective at diagnosis.

\section{Resistance to FLT3 inhibition}

Thus far, none of the FLT3 inhibitors under clinical investigation has elicited a sustained clinical response when used as a single agent. As an example, a phase I clinical trial for KW2449 showed that FLT3 inhibition in patients occurred only transiently to less than $20 \%$ of baseline levels (Pratz et al., 2009). It has been suggested that partial and transient FLT3 inhibition such as this applies to other FLT3 inhibitors in clinical development and may be responsible for their limited efficacy (Chu and Small, 2009).

One putative resistance mechanism related to FLT3 inhibition is dysregulation of signaling molecules, such as those associated with the PI3K/Akt and Ras/MEK/MAPK pathways (Piloto et al., 2007). Also implicated in drug resistance are aberrant STAT signaling (Zhou et al., 2009), the aberrant expression of the STAT5 target gene, PIM (Kim et al., 2005; Kim et al., 2006), and high levels of phosphoprotein expression of the forkhead transcription factor, FOXO3A (Kornblau et al., 2010). Additional mechanisms include up-regulation of antiapoptotic proteins (Kohl et al., 2007; Brietenbuecher et al., 2009; Stolzel et al., 2010), upregulation of inhibitors of apoptosis proteins, and elevated FLT3 ligand levels (Zhou et al., 2009). The concentration of FLT3 ligand has been observed to be significantly higher in 
patients treated with chemotherapy or radiotherapy (Lyman et al., 1995; Wodnar-Filipowicz et al., 1996; Zwierzina et al., 1999; Bojko et al., 2002), and this is predicted to impede the action of FLT3 inhibitors administered after chemotherapy.

Another possible resistance mechanism is cytoprotection conferred by the bone marrow microenvironment. Indeed, FLT3 inhibition was found to actually enhance the survival of CD34+CD38-CD123+ leukemic stem cells and progenitor cells in a "niche-like" in vitro microenvironment that was comprised of factors including IL-6, IL-3, stem cell factor (SCF), and immobilized fibronectin (Mony et al., 2008). Small molecule CXCR4 inhibitors may be effective in enhancing kinase inhibitor-induced apoptosis of stromal-protected leukemic cells, implicating a causal relationship between the chemokine receptor CXCR4 and stromaderived factor 1alpha (SDF-1a) interaction and drug-resistant leukemia (Zeng et al., 2006).

Pre-existing or acquired point mutations in the FLT3 kinase domain that interfere with drug binding may also contribute to drug resistance in patients (Cools et al., 2004; Heidel et al., 2006).

Point mutations in the FLT3 receptor are generally analogous to point mutations in BCR$\mathrm{ABL}$, the most prevalent mechanism of resistance to imatinib. However, there is little evidence for the existence of overlapping resistance profiles for FLT3 inhibitors, such as those demonstrated for imatinib, dasatinib, and nilotinib with respect to the T315I gatekeeper mutation (Von Bubnoff et al., 2006; Bradeen et al., 2006; Ray et al., 2007). Instead, non-overlapping mechanisms of resistance between PKC412, sorafenib, and SU5614 were found in a screening assay designed to study drug resistance profiles (Von Bubnoff et al., 2009). For example, SU5614 resistance was characterized predominantly as mutations in the D835 residue, while sorafenib resistance was characterized by unique mutations such as F691L and point mutations in the Y842 residue (Von Bubnoff et al., 2009). Another study confirmed the involvement of acquired mutations, $\mathrm{D} 835 \mathrm{~N}$ and $\mathrm{Y} 842 \mathrm{H}$, in resistance to SU5614 (Bagrintseva et al., 2004). In contrast, PKC412 resistance was characterized by mutations in the N676 residue, which was previously identified and characterized in a PKC412-resistant AML patient as the sole determinant of drug resistance (Heidel et al., 2006).

In addition to non-overlapping mutagenicity profiles between existing FLT3 inhibitors, each shows variable activity toward different mutations, for example activation loop mutants versus ITD mutations. As an example, sunitinib inhibits ITD and activation loop mutants with equal potency, whereas sorafenib is less efficacious toward activation loop mutants than ITD (Kancha et al., 2007). PKC412 shows comparable activity against different FLT3 activation loop mutants, whereas MLN518 shows variable activity (Clark et al., 2004; Barry et al., 2007).

Combination therapy as an approach to treating mutant FLT3-positive disease

As responses of patients to FLT3 inhibition is generally only partial and transient, there is a need for development of novel agents that can either be used effectively alone or combined with FLT3 inhibitors to suppress disease progression and prolong lifespan. FLT3 inhibitors have been tested in combination with standard chemotherapy agents as an approach to assessing the overall efficacy of combined therapies. For example, SU11248, combined with cytarabine or daunorubicin, exhibited additive-to-synergistic inhibitory effects on cells expressing mutant FLT3 (Yee et al., 2004). Similarly, CEP-701 showed synergy when combined with etoposide, mitoxantrone, daunorubicin, and cytarabine (Levis et al., 2004). PKC412 demonstrated synergy when combined with vincristine, 4-hydroperoxy- 
cyclophosphamide, etoposide, mitoxantrone, cytarabine, doxorubicin, and idarubicin (Mollgard et al., 2008; Furukawa et al., 2007). The sequence of administration of FLT3 inhibitors and standard chemotherapy appears to often, depending on the FLT3 inhibitor, be sequence-dependent, resulting in antagonism when the FLT3 inhibitor is administered prior to chemotherapy and resulting in synergy when the FLT3 inhibitor is administered after chemotherapy (Pratz and Levis, 2008).

One strategy geared toward overriding resistance to FLT3 inhibition includes the combined use of more than one FLT3 inhibitor, providing their interaction with the FLT3 protein target or FLT3 signaling pathway components is distinct enough for the two inhibitors to synergize. We demonstrated the potent and selective activity of the novel type II ATP competitive inhibitors, HG-7-85-01 and HG-7-86-01, against mutant FLT3, as well as their ability to synergize well with standard chemotherapeutic agents or midostaurin (Weisberg et al., 2010b). The ability of HG-7-85-01 and HG-7-86-01 to inhibit mutant FLT3, in addition to a number of gatekeeper mutants of multiple kinases of therapeutic interest, highlights their unique versatility and potential widespread clinical usefulness. Other potent FLT3 inhibitors, such as NVP-AST487, have the ability to effectively combine with midostaurin to kill drug-sensitive and insensitive mutant FLT3-expressing cells (Weisberg et al., 2008b). The ability of two targeted FLT3 inhibitors to synergize may translate into clinical benefit in terms of reducing toxicity, as clinical responses achieved with late-stage FLT3 inhibitors like midostaurin and CEP-701 depend on combined administration with standard chemotherapeutic agents.

Alternatively, FLT3 inhibitors can be combined with small molecule inhibitors that interact with key mediators of major signaling pathways that play a significant role in AML. Crosstalk between the three main pathways activated by mutant FLT3 (RAS/Raf/MEK/ERK, Jak/STAT, and PI3K/PTEN/Akt/mTOR) warrants the development of multi-targeted approaches for treatment of mutant FLT3-positive AML (Brandts et al., 2005; Recher et al., 2005; Kornblau et al., 2006; Rocnik et al., 2006; Al Shaer et al., 2008). We have shown that signaling pathway inhibitors, such as the dual PI3K/PDK-1 inhibitor, BAG956, can positively combine with midostaurin against mutant FLT3-positive cells (Weisberg et al., 2008a). Of relevance, PKC412 and the mTOR inhibitor, rapamycin, synergize against PKC412-sensitive and -resistant mutant FLT3-expressing cells (Mohi et al., 2004). The rapamycin derivative, RAD001, enhances the anti-leukemic effects of sunitinib (Ikezoe et al., 2006), as does the MEK1/2 kinase inhibitor, AZD6244 (ARRY-142886) (Nishioka et al., 2008b). Other agents effective in killing mutant FLT3-expressing cells are heat shock protein 90 (Hsp90) inhibitors and histone deacetylase inhibitors, which disrupt the major signaling pathways (Al Shaer et al., 2008; Nishioka et al., 2008a), and drugs that inhibit farnesyltransferase (Mollgard et al., 2008).

\section{Characterization of underlying mechanisms of stroma-mediated chemoresistance to tyrosine kinase inhibition}

In addition to identifying and developing potent kinase inhibitors representative of novel and unique structural classes with the ability to override drug resistance due to changes in the target protein, there is a push toward gaining a better understanding of the mechanisms underlying drug resistance in CML and AML as they relate to the leukemic cell microenvironment. Bone marrow is comprised of hematopoietic and stromal cells, in addition to other factors including extracellular matrix and blood vessels; growth factors 
and cell:cell interactions (Charbord et al. 1996). Bone marrow stroma and factors derived from stroma have been suggested to play a role in the long-term survival and proliferation of normal and leukemia cells (Ashley et al., 1994; Bradstock et al., 1996; Rafii et al., 1997; Lagneaux et al., 1998, Lagneaux et al., 1999; Konopleva et al., 2002; Litwin et al., 2002). Specifically, bone marrow stroma provides signals, such as granulocyte colony-stimulating factor (G-CSF), granulocyte macrophage colony-stimulating factor (GM-CSF), and terminal differentiation of hematopoietic stem cells or mediate/support their proliferation (Verfaillie et al., 1993; Liesveld et al., 1996; Harrison et al., 1997; Breems et al., 1997; O'Prey et al., 1998; Leslie et al., 1998; Shih et al., 1999). SSpenic stroma, as well, has been implicated in enhanced survival of both normal and leukemic cells (Shaked et al., 2005; Despars and O'Neill, 2006). Clinical trial data with tyrosine kinase inhibitors show that while the peripheral blood of patients responds well, bone marrow responds less well. It appears possible that small numbers of leukemic CD34+ cells can persist in the marrow microenvironment of leukemia patients after years of therapy with kinase inhibitors. Stromal cells have been implicated, as they provide viability signals to leukemic cells that protect them from inhibitor effects. Indeed, the quantity of leukemic stem cells that rely on stroma to survive is predictive of disease outcome (Kumagai et al., 1996).

We revealed highest tumor burden and residual disease to occur in vivo in stroma-associated tissues in imatinib/nilotinib-treated NCr nude mice, suggesting that significant reservoirs for tumor growth appear to be tissues that are able to support normal hematopoietic and malignant stem cell development (Weisberg et al., 2008c). These studies, which showed a pattern of leukemia distribution consistent with what is observed in imatinib- and nilotinibtreated chronic myeloid leukemia patients, were followed by a more in-depth analysis of stroma-leukemia cell interactions that lead to protection of leukemia cells from nilotinibinduced cytotoxicity. For the latter, we used the human BCR-ABL-positive cell line, KU812F, and the human bone marrow stroma cell line, HS-5, to more closely approximate the bone marrow-associated cytoprotection observed in drug-treated leukemia patients. Partial stromal-mediated protection of BCR-ABL-positive leukemic cells from nilotinib treatment involved the cooperative interaction of members of a select panel of stromal-secreted viability factors, including IL-6 and GM-CSF (Weisberg et al., 2008c). Similar results were observed with mutant FLT3-positive leukemia cells treated with midostaurin in the presence of HS-5-stromal-conditioned media versus the same panel of stromal-secreted viability factors (Weisberg et al., 2009).

\section{Potentiation of anti-leukemic effects of tyrosine kinase inhibitors by IAP inhibition: Implications for use of IAP inhibition to prevent or reduce residual disease following tyrosine kinase inhibition}

Deregulated signaling molecules associated with viability/apoptotic signaling represent attractive targets for therapeutic intervention, and several strategies have emerged that may be effective in preventing drug resistance due to this. One approach involves combining targeted inhibitors with small molecule inhibitors of key components of major signaling pathways affecting the viability/expansion of leukemic cells. Accordingly, we have developed effective inhibitors of the inhibitor of apoptosis (IAP) family of proteins (Liu et al., 2000; Wu et al., 2000), such as LBW242 (Weisberg et al., 2007b), and its structural analog, LCL161, which bind to and inhibit multiple IAPs (i.e. XIAP, c-IAP) to enhance the activity of different proapoptotic signaling pathways. We have demonstrated the ability of LBW242 to 
synergize with midostaurin in vivo against progressive mutant FLT3-positive leukemia and to override stromal-mediated chemoresistance in vitro (Weisberg et al., 2007b).

Clinical trial data with midostaurin show that while good responses are achievable in mutant FLT3-positive AML patient peripheral blood, patient bone marrow responses are more modest. This suggests that stromal cells provide viability signals to AML cells that protect the cells from the effects of the selective inhibitor being used. We investigated the responsiveness of $\mathrm{Ba} / \mathrm{F3}-\mathrm{FLT3}-\mathrm{ITD}$ cells cultured in the presence and absence of WEHI (used as a source of IL-3) to the cytotoxic effects of midostaurin, and we found that the presence of IL-3 completely protected cells from midostaurin-inhibition of cellular proliferation (Weisberg et al., 2007b). In contrast to midostaurin, the IAP inhibitor, LBW242, inhibited Ba/F3-FLT3-ITD proliferation in both the absence and the presence of IL-3 (Weisberg et al., 2007b). Interestingly, LBW242 plus midostaurin inhibited the growth of $\mathrm{Ba} / \mathrm{F} 3-\mathrm{FLT3}-\mathrm{ITD}$ cells cultured in the presence of IL-3 to a greater extent than either agent alone; this inhibition was similar to that achieved with co-administration of both agents in the absence of IL-3, suggesting that an IAP inhibitor is able to enhance the effects of a FLT3 inhibitor and override chemoresistance due to provision of viability signals (Weisberg et al., 2007b).

In an attempt to more closely model putative stromal-AML cell interactions and stromalmediated viability signaling effects on the cytotoxic effects of midostaurin, we tested the human stroma cell line, HS-5, in combination with the mutant FLT3 AML line, MOLM-13-luc+ (luciferase was used to specifically quantify only the leukemia component in the assay using light emission). A confluent layer of HS-5 stromal cells enhanced the growth of MOLM13-luc+ cells and was partially protective against the inhibitory effects of midostaurin (Weisberg et al., 2007b). LBW242 enhanced the cytotoxic effects of midostaurin against MOLM13-luc+ cells in the presence of HS-5 human stromal cells, supporting the notion that stromal-mediated viability signals may contribute to chemoresistance to FLT3 inhibitors

(such as midostaurin) observed in marrow, as well as the idea that such resistance may be overcome by inclusion of IAP inhibitor treatment (Weisberg et al., 2007b).

We have also shown the ability of LCL161 to significantly delay disease recurrence in mice injected with BCR-ABL-expressing cells and treated for several weeks with a moderate dose of nilotinib (Weisberg et al., 2010d). Specifically, using in vitro models of intrinsic drug resistance and stromal-mediated chemoresistance, as well as functional mouse models of progressive and residual disease, we showed the ability of the novel IAP inhibitor, LCL161, to enhance the cytotoxic effects of tyrosine kinase inhibitors against leukemic disease. Importantly, we observed LCL161 to synergize in vivo with nilotinib to reduce leukemia burden significantly below the baseline level suppression exhibited by a moderate-to-high dose of nilotinib. Our results support the idea of using IAP inhibitors in conjunction with targeted tyrosine kinase inhibition to suppress or eradicate progressive and drug-resistant or residual disease. Phase I studies in advanced solid tumors are currently ongoing, and LCL161 is being considered for testing in clinical trials for leukemia.

\section{Conclusion}

Elucidation of mechanisms of resistance to tyrosine kinase inhibition is critical for the optimization of existing therapies and prolongation of patient survival via delaying or eradicating the recurrence of disease. For CML, the discovery and characterization of BCR$\mathrm{ABL}$ point mutations in the kinase target of a number of inhibitors in clinical use has been a 
tremendous step forward in understanding an important underlying mechanism of drug resistance. While second generation BCR-ABL inhibitors, such as nilotinib and dasatinib, have proven to be highly effective in the clinic and override imatinib resistance to an extent, the existence of highly imatinib-resistant mutants, such as the T315I gatekeeper mutant, is a limiting factor. Even for third generation BCR-ABL inhibitors that are able to override T315I, the potential exists for the evolution of novel drug-resistant point mutations that impede the binding of drug to its target. Thus, there continues to be a need for development of BCR$\mathrm{ABL}$ inhibitors with high potency and unique mutagenicity profiles, as well as a continued need for combination therapy approaches to overriding drug resistance.

For mutant FLT3-positive AML, due to the only transient and partial effects observed clinically with FLT3 inhibitors in late-stage development, there is an urgent need for the development of new treatment approaches that could potentially lead to improved clinical effectiveness. As with CML, the key to improved patient responsiveness may lie in continued development of compounds conferring a higher degree of potency, as well as novel combination therapy strategies.

For both CML and mutant FLT3-positive AML, elucidation of mechanisms of resistance that are associated with leukemic cell survival, such as stromal-mediated chemoresistance and up-regulation of viability signaling molecules, warrants the investigation of single agent activity of pro-apoptotic agents. It also warrants the development of treatment approaches that rely on administration of kinase inhibitors combined with other agents targeting components of leukemia:stromal cell interactions and stromal-derived viability factors.

\section{References}

Adrian, F.J., Ding, Q., Sim, T., Velentza, A., Sloan, C., Liu, Y., Zhang, G., Hur, W., Ding, S., Manley, P., Mestan, J., Fabbro, D., \& Gray, N.S. (2006). Allosteric inhibitors of Bcrabl-dependent cell proliferation. Nat Chem Biol, Feb;2 (2), pp. 95-102.

Albert, D.H., Tapang, P., Magoc, T.J., Pease, L.J., Reuter, D.R., Wei, R.Q., Li, J., Guo, J., Bousquet, P.F., Ghoreishi-Haack, N.S., Wang, B., Bukofzer, G.T., Wang, Y.C., Stavropoulos, J.A., Hartandi, K., Niquette, A.L., Soni, N., Johnson, E.F., McCall, J.O., Bouska, J.J., Luo, Y., Donawho, C.K., Dai, Y., Marcotte, P.A., Glaser, K.B., Michaelides, M.R., \& Davidsen, S.K. (2006). Preclinical activity of ABT-869: a multitargeted receptor tyrosine kinase inhibitor. Mol Cancer Ther, Apr;5(4), pp. 9951006.

Al Shaer, L., Walsby, E., Gilkes, A., Tonks, A., Walsh, V., Mills, K., Burnett, A., \& Rowntree, C. (2008). Heat shock protein 90 inhibition is cytotoxic to primary AML cells expressing mutant FLT3 and results in altered downstream signaling. Br J Haematol, May;141(4), pp. 483-493.

Ashley, D.M., Bol, S.J., \& Kannourakis G. (1994). Human bone marrow stromal cell contact and soluble factors have different effects on the survival and proliferation of paediatric B-lineage acute lymphoblastic leukaemic blasts. Leuk Res, May;18(5), pp. 337-346.

Auclair, D., Miller, D., Yatsula, V., Pickett, W., Carter, C., Chang, Y., Zhang, X., Wilkie, D., Burd, A., Shi, H., Rocks, S., Gedrich, R., Abriola, L., Vasavada, H., Lynch, M., Dumas, J., Trail, P.A., \& Wilhelm, S.M. (2007). Antitumor activity of sorafenib in FLT3-driven leukemic cells. Leukemia, Mar;21(3), pp. 439-445. 
Azam, M., Latek, R. R. \& Daley, G. Q. (2003). Mechanism of autoinhibition and STI$571 /$ imatinib resistance revealed by mutagenesis of BCR-ABL. Cell, Mar 21;112(6), pp. 831-843.

Bagrintseva, K., Schwab, R., Kohl, T.M., Schnittger, S., Eichenlaub, S., Ellwart, J.W., Hiddemann, W., \& Spiekermann, K. (2004). Mutations in the tyrosine kinase domain of FLT3 define a new molecular mechanism of acquired drug resistance to PTK inhibitors in FLT3-ITD-transformed hematopoietic cells. Blood, Mar 15;103(6), pp. 2266-2275.

Barry, E.V., Clark, J.J., Cools, J., Roesel, J., \& Gilliland, D.G. (2007). Uniform sensitivity of FLT3 activation loop mutants to the tyrosine kinase inhibitor midostaurin. Blood, Dec 15;110(13), pp. 4476-4479.

Bojko, P., Pawloski, D., Stellberg, W., Schroder, J.K., \& Seeber, S. (2002). Flt3 ligand and thrombopoietin serum levels during peripheral blood stem cell mobilization with chemotherapy and recombinant human glycosylated granulocyte colonystimulating factor (rhu-G-CSF, lenograstim) and after high-dose chemotherapy. Ann Hematol, Sep;81(9), pp. 522-528.

Bradeen, H.A., Eide, C.A., O’Hare, T., Johnson, K.J., Willis, S.G., Lee, F.Y., Druker, B.J., \& Deininger, M.W. (2006). Comparison of imatinib mesylate, dasatinib (BMS-354825), and nilotinib (AMN107) in an N-ethyl-N-nitrosourea (ENU)-based mutagenesis screen: high efficacy of drug combinations. Blood, 108(7), pp. 2332-8.

Bradstock, K., Bianchi, A., Makrynikola, V., Filshie, R., \& Gottlieb, D. (1996). Long-term survival and proliferation of precursor B acute lymphoblastic leukemia cells on human bone marrow stroma. Leukemia, May;10(5), pp. 813-820.

Brandts, C.H., Sargin, B., Rode, M., Biermann, C., Lindtner, B., Schwable, J., Buerger, H., Muller-Tidow, C., Choudhary, C., McMahon, M., Berdel, W.E., \& Serve, H. (2005). Constitutive activation of Akt by Flt3 internal tandem duplications is necessary for increased survival, proliferation, and myeloid transformation. Cancer Res, Nov 1;65(21), pp. 9643-9650.

Breems, D.A., Blokland, E.A., \& Ploemacher, R.E. (1997). Stroma-conditioned media improve expansion of human primitive hematopoietic stem cells and progenitor cells. Leukemia, Jan;11(1), pp. 142-50.

Breitenbuecher, F., Markova, B., Kasper, S., Carius, B., Stauder, T., Bohmer, F.D., Masson, K., Ronnstrand, L., Huber, C., Kindler, T., \& Fischer, T. (2009). A novel molecular mechanism of primary resistance to FLT3-kinase inhibitors in acute myeloid leukemia. Blood, Apr 23;113(17), pp. 4063-73.

Burgess, M.R., Skaggs, B.J., Shah, N.P., Lee, F.Y., \& Sawyers, C.L. (2005). Comparative analysis of two clinically active BCR-ABL kinase inhibitors reveals the role of conformation-specific binding in resistance. Proc Natl Acad Sci USA, Mar 1;102(9), pp. 3395-3400.

Buchdunger, E., Matter, A., \& Druker, B.J. (2001). Bcr-Abl inhibition as a modality of CML therapeutics. Biochim Biophys Acta, Aug 31;1551(1), pp. M11-M18.

Carter, T. A., Wodicka, L.M., Shah, N.P., Velasco, A.M., Fabian, M.A., Treiber, D.K., Milanov, Z.V., Atteridge, C.E., Biggs, W.H. 3rd, Edeen, P.T., Floyd, M., Ford, J.M., Grotzfeld, R.M., Herrgard, S., Insko, D.E., Mehta, S.A., Patel, H.K., Pao, W., Sawyers, C.L., Varmus, H., Zarrinkar, P.P., \& Lockhart, D.J. (2005). Inhibition of drug-resistant mutants of ABL, KIT, and EGF receptor kinases. Proc. Natl Acad. Sci, USA Aug 2;102(31), pp. 11011-11016. 
Chao, Q., Sprankle, K.G., Grotzfeld, R.M., Lai, A.G., Carter, T.A., Velasco, A.M., Gunawardane, R.N., Cramer, M.D., Gardner, M.F., James, J., Zarrinkar, P.P., Patel, H.K., \& Bhagwat, S.S. (2009). Identification of N-(5-tert-butyl-isoxazol-3-yl)-N'\{4-[7(2-morpholin-4-yl-ethoxy)imidazo[2,1-b][1,3]benzothiazol-2-yl]phenyl\}urea dihydrochloride (AC220), a uniquely potent, selective, and efficacious FMS-like tyrosine kianse-3 (FLT3) inhibitor. J Med Chem, Dec 10;52(23), pp. 7808-7816.

Charbord, P., Tavian, M., Humeau, L., \& Peault, B. (1996). Early ontogeny of the human marrow from long bones: an immunohistochemical study of hematopoiesis and its microenvironment. Blood, May 15;87(10), pp. 4109-4119.

Cheng Y. \& Paz K. (2008). Tandutinib, an oral, small molecule inhibitor of FLT3 for the treatment of AML and other cancer indications. IDrugs, Jan;11(1), pp. 46-56.

Choi, H.G., Ren, P., Adrian, F., Sun, F., Lee, H.S., Wang, X., Ding, Q., Zhang, G., Xie, Y., Zhang, J., Liu, Y., Tuntland, T., Warmuth, M., Manley, P.W., Mestan J., Gray N.S., \& Sim T. (2010). A type-II kinase inhibitor capable of inhibiting the T315I "gatekeeper" mutant of Bcr-Abl. J Med Chem, Aug 12;53(15), pp. 5439-48.

Chu, S.H. \& Small, D. (2009). Mechanisms of resistance to FLT3 inhibitors. Drug Resist Updates, Apr;12(1-2), pp. 8-16.

Clark, J.J., Cools, J., Curley, D.P., Yu, J.C., Lokker, N.A., Giese, N.A., \& Gilliland, D.G. (2004). Variable sensitivity of FLT3 activation loop mutations to the small molecule tyrosine kinase inhibitor MLN518. Blood, Nov 1;104(9), pp. 2867-2872.

Cools, J., Mentens, N., Furet, P., Fabbro, D., Clark, J.J., Griffin, J.D., Marynen, P., \& Gilliland, D.G. (2004). Prediction of resistance to small molecule FLT3 inhibitors: Implications for molecularly targeted therapy of acute leukemia. Cancer Res, Sept 15;64(18), pp. 6385-6389.

Copland, M., Hamilton, A., Elrick, L.J., Baird, J.W., Allan, E.K., Jordanides, N., Barow, M., Mountford, J.C., \& Holyoake, T.L. (2006). Dasatinib (BMS-354825) targets an earlier progenitor population than imatinib in primary CML but does not eliminate the quiescent fraction. Blood, Jun 1;107(11), pp. 4532-4539.

Corbin, A. S., Buchdunger, E., Pascal, F. \& Druker, B. J. (2002). Analysis of the structural basis of specificity of inhibition of the ABL kinase by STI-571. J. Biol. Chem, Aug 30;277(35), pp. 32214-32219.

Cowan-Jacob, S. W., Guez, V., Fendrich, G., Griffin, J.D., Fabbro, D., Furet, P., Liebetanz, J., Mestan, J., \& Manley, P.W. (2004). Imatinib (STI571) resistance in chronic myelogenous leukemia: molecular basis of the underlying mechanisms and potential strategies for treatment. Mini Rev. Med. Chem, Mar;4(3), pp. 285-299.

Deininger, M.W., Goldman, J.M., \& Melo, JV. (2000). The molecular biology of chronic myeloid leukemia. Blood, Nov 15;96(10), pp. 3343-3356. PMID: 11071626.

Druker, B.J., Tamura, S., Buchdunger, E., Ohno, S., Segal, G.M., Fanning, S., Zimmermann, J., \& Lydon, N.B. Effects of a selective inhibitor of the Abl tyrosine kinase on the growth of Bcr-Abl positive cells. (1996). Nat Med, May;2(5), pp. 561-566.

Despars, G. \& O'Neill, H.C. (2006). Splenic endothelial cell lines support development of dendritic cells from bone marrow. Stem Cells, Jun;24(6), pp. 1496-1504.

Donato, N. J., Wu, J.Y., Stapley, J., Gallick, G., Lin, H., Arlinghaus, R., \& Talpaz, M. (2003). BCR-ABL independence and LYN kinase overexpression in chronic myelogenous leukemia cells selected for resistance to STI571. Blood, Jan $15 ; 101(2)$, pp. 690-698. 
Engler, J.R., Frede, A., Saunders, V.A., Zannettino, A.C., Hughes, T.P., \& White, D.L. (2010). Chronic myeloid leukemia CD34+ cells have reduced uptake of imatinib due to low OCT-1 activity. Leukemia, Apr;24(4), pp. 765-70.

Fancelli, D., Moll J., Varasi, M., Bravo, R., Artico, R., Berta, D., Bindi, S., Cameron, A., Candiani, I., Cappella, P., Carpinelli, P., Croci, W., Forte, B., Giorgini, M.L., Klapwijk, J., Marsiglio, A., Pesenti, E., Rocchetti, M., Roletto, F., Severino, D., Soncini, C., Storici, P., Tonani, R., Zugnoni, P., \& Vianello, P. (2006). 1, 4, 5, 6Tetrahydropyrrolo[3, 4-c]pyrazoles: identification of a potent aurora kinase inhibitor with a favorable antitumor kinase inhibition profile. J. Med. Chem, Nov 30;49(24), pp. 7247-7251.

Fiedler, W., Mesters, R., Tinnefeld, H., Loges, S., Staib, P., Duhrsen, U., Flasshove, M., Ottmann, O.G., Jung, W., Cavalli, F., Kuse, R., Thomalla, J., Serve, H., O'Farrell, A.M., Jacobs, M., Brega, N.M., Scigalla, P., Hossfeld, D.K., \& Berdel, W.E. (2003). A phase 2 clinical study of SU5416 in patients with refractory acute myeloid leukemia. Blood, Oct 15;102(8), pp. 2763-2767.

Fiedler, W., Serve, H., Dohner, H., Schwittay, M., Ottmann, O.G., O’Farrell, A.M., Bello, C.L., Allred, R., Manning, W.C., Cherrington, J.M., Louie, S.G., Hong, W., Brega, N.M., Massimini, G., Scigalla, P., Berdel, W.E., \& Hossfeld, D.K. (2005). A Phase I study of SU11248 in the treatment of patients with refractory or resistant acute myeloid leukemia (AML) or not amenable to conventional therapy for the disease. Blood, Feb 1;105(3), pp. 968-993.

Furukawa, Y., Vu, H.A., Akutsu, M., Odgerel, T., Izumi, T., Tsunoda, S., Matsuo, Y., Kirito, K., Sato, Y., Mano, H., \& Kano, Y. (2007). Divergent cytotoxic effects of PKC412 in combination with conventional antileukemic agents in FLT3 mutation-positive versus -negative leukemia cell lines. Leukemia, May;21(5), pp. 1005-1014.

Galban, S., Hwang, C., Rumble, J.M., Oetien, K.A., Wright, C.W., Boudreault, A., Durkin, J., Gillard, J.W., Jaquith, J.B., Morris, S.J., \& Duckett, C.S. (2009). Cytoprotective effects of IAPs revealed by a small molecule antagonist. Biochem J, Feb 1;417(3), pp. 765-771.

Gambacorti-Passerini, C., Barni, R., le Coutre, P., Zucchetti, M., Cabrita, G., Cleris, L., Rossi, F., Gianazza, E., Brueggen, J., Cozens, R., Pioltelli, P., Pogliani, E., Corneo, G., Formelli, F., \& D'Incalci, M. (2000). Role of alpha1 acid glycoprotein in the in vivo resistance of human BCR-ABL (+) leukemic cells to the abl inhibitor STI571. J Natl Cancer Inst, Oct 18;92(20), pp. 1641-50.

Giles, F.J., Cortes, J., Jones, D., Bergstrom, D., Kantarjian, H., \& Freedman, S.J. (2007). MK0457, a novel kinase inhibitor, is active in patients with chronic myeloid leukemia or acute lymphocytic leukemia with the T315I BCR-ABL mutation. Blood, Jan 15;109(2), pp. 500-2.

Giles, F.J., Stopeck, A.T., Silverman, L.R., Lancet, J.E., Cooper, M.A., Hannah, A.L., Cherrington, J.M., O'Farrell, A.M., Yuen, H.A., Louie, S.G., Hong, W., Cortes, J.E., Verstovsek, S., Albitar, M., O’Brien, S.M., Kantarjian, H.M., \& Karp, J.E. (2003). SU5416, a small molecule tyrosine kinase receptor inhibitor, has biologic activity in patients with refractory acute myeloid leukemia or myelodysplastic syndromes. Blood, Aug 1;102(3), pp. 795-801.

Golas, J. M., Arndt, K., Etienne, C., Lucas, J., Nardin, D., Gibbons, J., Frost, P., Ye, F., Boschelli, D.H., \& Boschelli, F. (2003). SKI-606, a 4-anilino-3-quinolinecarbonitrile dual inhibitor of SRC and ABL kinases, is a potent antiproliferative agent against 
chronic myelogenous leukemia cells in culture and causes regression of K562 xenografts in nude mice. Cancer Res, Jan 15;63(2), pp. 375-381.

Goldman, J.M. \& Melo, J.V. (2003). Chronic myeloid leukemia-advances in biology and new approaches to treatment. N Engl J Med Oct 9;349(15):1451-64.

Gorre, M. E., Mohammed, M., Ellwood, K., Hsu, N., Paquette, R., Rao, P.N., \& Sawyers, C.L. (2001). Clinical resistance to STI-571 cancer therapy caused by BCR-ABL gene mutation or amplification. Science, Aug 3;293(5531), pp. 876-880.

Gozgit, J.M., Wong, M.J., Wardwell, S., Tyner, J.W., Loriaux, M.M., Mohemmad, Q.K., Narasimhan, N.I., Shakespeare, W.C., Wang, F., Druker, B.J., Clackson, T., Rivera, V.M. (2011). Potent activity of Ponatinib (AP24534) in models of FLT3-driven acute myeloid leukemia and other hematologic malignancies. Mol Cancer Ther, Jun;10(6), pp. 1028-1035.

Guerrouahen, B.S., Futami, M., Vaklavas, C., Kanerva, J., Whichard, Z.L., Nwawka, K., Blanchard, E.G., Lee, F.Y., Robinson, L.J., Arceci, R., Kornblau, S.M., Wieder, E., Cayre, Y.E., \& Corey, S.J. (2010). Dasatinib inhibits the growth of molecularly heterogeneous myeloid leukemias. Clin Cancer Res, Feb 15;16(4), pp. 1149-1158.

Harrison, P.R., Nibbs, R.J., Bartholomew, C., O'Prey, J., Qiu, J., Walker, M., Clark, A.M., Leslie, N., \& Ostertag, W. (1997). Molecular mechanisms involved in long-term maintenance of erythroleukaemia cells by stromal cells. Leukemia, Apr;11:(suppl 3), pp. 474-477.

Heidel, F., Solem, F.K., Breitenbuecher, F., Lipka, D.B., Kasper, S., Thiede, M.H., Brandts, C., Serve, H., Roesel, J., Giles, F., Feldman, E., Ehninger, G., Schiller, G.J., Nimer, S., Stone, R.M., Wang, Y., Kindler, T., Cohen, P.S., Huber, C., \& Fischer, T. (2006). Clinical resistance to the kinase inhibitor PKC412 in acute myeloid leukemia by mutation of Asn-676 in the FLT3 tyrosine kinase domain. Blood, Jan 1;107(1), pp. 293-300.

Hennequin, L. F., Allen, J., Breed, J., Curwen, J., Fennell, M., Green, T.P., Lambert-van der Brempt, C., Morgentin, R., Norman, R.A., Olivier, A., Otterbein, L., Ple, P.A., Warin, N., \& Costello, G. (2006). N-(5-Chloro-1, 3-benzodioxol-4-yl)-7-[2-(4methylpiperazin-1-yl)ethoxy]-5- (tetrahydro-2H-pyran-4-yloxy)quinazolin-4-amine, a novel, highly selective, orally available, dual-specific c-Src/Abl kinase inhibitor. J. Med. Chem, Nov 2;49(22), pp. 6465-6488.

Hochhaus, A., Kreil, S., Corbin, A.S., La Rosee, P., Muller, M.C., Lahaye, T., Hanfstein, B., Schoch, C., Cross, N.C., Berger, U., Gschaidmeier, H., Druker, B.J., \& Hehlmann, R. (2002). Molecular and chromosomal mechanisms of resistance to imatinib (STI571) therapy. Leukemia, Nov;16(11), pp. 2190-2196.

Hofmann, W. K., Komor, M., Wassmann, B., Jones, L.C., Gschaidmeier, H., Hoelzer, D., Koeffler, H.P., \& Ottmann, O.G. (2003). Presence of the BCR-ABL mutation Glu255Lys prior to STI571 (imatinib) treatment in patients with $\mathrm{Ph}+$ acute lymphoblastic leukemia. Blood, July 15;102(2), pp. 659-661.

Horiike, S., Yokota, S., Nakao, M., Iwai, T., Sasai, Y., Kaneko, H., Taniwaki, M., Kashima, K., Fujii, H., Abe, T., \& Misawa, S. (1997). Tandem duplications of the FLT3 receptor gene are associated with leukemic transformation of myelodysplasia. Leukemia, Sep;11(9), pp. 1442-1446.

Ikezoe, T., Nishioka, C., Tasaka, T., Yang, Y., Komatsu, N., Togitani, K., Koeffler, H.P., \& Taguchi, H. (2006). The antitumor effects of sunitinib (formerly SU11248) against a variety of human hematologic malignancies: enchancement of growth inhibition 
via inhibition of mammalian target of rapamycin signaling. Mol. Cancer Ther, Oct;5(10), pp. 2522-2530.

Jiang, J., Paez, J.G., Lee, J.C., Bo, R., Stone, R.M., DeAngelo, D.J., Galinsky, I., Wolpin, B.M., Jonasova, A., Herman, P., Fox, E.A., Boggon, T.J., Ecki, M.J., Weisberg, E., Griffin, J.D., Gilliland, D.G., Meyerson, M., \& Sellers, W.R. (2004). Identifying and characterizing a novel activating mutation of the FLT3 tyrosine kinase in AML. Blood, Sep 15;104(6), pp. 1855-1858.

Kancha, R.K., Grundler, R., Peschel, C., \& Duyster, J. (2007). Sensitivity toward sorafenib and sunitinib varies between different activating and drug-resistant FLT3-ITD mutations. Exp Hematol, Oct;35(10), pp. 1522-1526.

Kantarjian, H., Shah, N.P., Hochhaus, A., Cortes, J., Shah, S., Ayala, M., Moiraghi, B., Shen, Z., Mayer, J., Pasquini, R., Nakamae, H., Huguet, F., Boque, C., Chuah, C., Bleickardt, E., Bradley-Garelik, M.B., Zhu, C., Szatrowski, T., Shapiro, D., \& Baccarani, M. (2010) Dasatinib versus imatinib in newly diagnosed chronic-phase chronic myeloid leukemia. N Engl J Med, June 17;362(24), pp. 2260-2270.

Kasper, S., Breitenbuecher, F., Hoehn, Y., Heidel, F., Lipka, D.B., Markova, B., Huber, C., Kindler, T., \& Fischer, T. (2008). The kinase inhibitor LS104 induces apoptosis, enhances cytotoxic effects of chemotherapeutic drugs and is targeting the receptor tyrosine kinase FLT3 in acute myeloid leukemia. Leuk Res, Nov;32(11), pp. 16981708.

Kelly, L.M., Liu, Q., Kutok, J.L., Williams, I.R., Boulton, C.L., \& Gilliland, D.G. (2002a). FLT3 internal tandem duplication mutations associated with human acute myeloid leukemias induce myeloproliferative disease in a murine bone marrow transplant model. Blood, Jan 1;99(1), pp. 310-318.

Kelly, L.M., Yu, J.C., Boulton, C.L., Apatira, M.M., Li, J., Sullivan, C.M., Williams, I., Amaral, S.M., Curley, D.P., Duclos, N., Neuberg, D., Scarborough, R.M., Pandey, A., Hollenbach, S., Abe, K., Lokker, N.A., Gilliland, D.G., \& Giese, N.A. (2002b). CT53518, a novel selective FLT3 antagonist for the treatment of acute myelogenous leukemia. Cancer Cell, Jun;1(5), pp. 421-432.

Kim, K.T., Baird, K., Ahn, J.Y., Meltzer, P., Lilly, M., Levis, M.,\& Small, D. (2005). Pim-1 is up-regulated by constitutively activated FLT3 and plays a role in FLT3-mediated cell survival. Blood, Feb 15;105(4), pp. 1759-1767.

Kim, K.T., Levis, M., \& Small, D. (2006). Constitutively activated FLT3 phosphorylates BAD partially through pim-1. Br J Haematol, Sept;134(5), pp. 500-509.

Kindler, T., Breitenbuecher, F., Kasper, S., Estey, E., Giles, F., Feldman, E., Ehninger, G., Schiller, G., Klimek, V., Nimer, S.D., Gratwohl, A., Choudhary, C.R., MuellerTidow, C., Serve, H., Gschaidmeier, H., Cohen, P.S., Huber, C., \& Fischer, T. (2005). Identification of a novel activating mutation (Y842C) within the activation loop of FLT3 in patients with acute myeloid leukemia (AML). Blood, Jan 1;105(1), pp. 335340.

Kiyoi, H., Towatari, M., Yokota, S., Hamaguchi, M., Ohno, R., Saito, H., \& Naoe, T. (1998). Internal tandem duplication of the FLT3 gene is a novel modality of elongation mutation which causes constitutive activation of the product. Leukemia, Sep;12(9), pp. 1333-1337.

Knapper, S., Burnett, A.K., Littlewood, T., Kell, W.J., Agrawal, S., Chopra, R., Clark, R., Levis, M.J., \& Small, D. (2006). A phase 2 trial of the FLT3 inhibitor lestaurtinib 
(CEP701) as first line treatment for older patients with acute myeloid leukemia not considered fit for intensive chemotherapy. Blood, Nov 15;108(10), pp. 3262-3270.

Kohl, T.M., Hellinger, C., Ahmed, F., Buske, C., Hiddermann, W., Bohlander, S.K., \& Spiekermann, K. (2007). BH3 mimetic ABT-737 neutralizes resistance to FLT3 inhibitor treatment mediated by FLT3independent expression of BCL2 in primary AML blasts. Leukemia, Aug;21(8), pp. 1763-1772.

Kondo, M., Horibe, K., Takahashi, Y., Matsumoto, K., Fukuda, M., Inaba, J., Kato, K., Kojima, S., \& Matsuyama, T. (1999). Prognostic value of internal tandem duplication of the FLT3 gene in childhood acute myelogenous leukemia. Med Pediatr Oncol, Dec;33(6), pp. 525-529.

Konopleva, M., Konoplev, S., Hu, W., Zaritskey, A.Y., Afanasiev, B.V., \& Andreeff, M. (2002). Stromal cells prevent apoptosis of AML cells by up-regulation of antiapoptotic proteins. Leukemia, Sept;1(9)6, pp. 1713-1724.

Kornblau, S.M., Womble, M., Qiu, Y.H., Jackson, C.E., Chen, W., Konopleva, M., Estey, E.H., \& Andreeff, M. (2006). Simultaneous activation of multiple signal transduction pathways confers poor prognosis in acute myelogenous leukemia. Blood, Oct 1;108(7), pp. 2358-2365.

Kornblau, S.M., Singh, N., Qiu, Y., Chen, W., Zhang, N., \& Coombes, K.R. (2010). Highly phosphorylated FOXO3A is an adverse prognostic factor in acute myeloid leukemia. Clin Cancer Res, Mar 15;16(6), pp. 1865-1874.

Kumagai, M., Manabe, A., Pui, C.H., Behm, F.G., Raimondi, S.C., Hancock, M.L., Mahmoud, H., Crist, W.M., \& Campana, D. (1996). Stroma-supported culture in childhood Blineage acute lymphoblastic leukemia cells predicts treatment outcome. J Clin Invest, Feb 1;97(3), pp. 755-760.

Kuroda, J., Puthalakath, H., Cragg, M.S., Kelly, P.N., Bouillet, P., Huang, D.C., Kimura, S., Ottmann, O.G., Druker, B.J., Villunger, A., Roberts, A.W.,\& Strasser, A. (2006). Bim and Bad mediate imatinib-induced killing of Bcr/Abl+ leukemic cells, and resistance due to their loss is overcome by a BH3 mimetic. Proc Natl Acad Sci USA, Oct 3;103(40), pp. 14907-14912.

Lagneaux, L., Delforge, A., Bron, D., De Bruyn, C., \& Stryckmans, P. (1998). Chronic lymphocytic leukemic B cells but not normal B cells are rescued from apoptosis by contact with normal bone marrow stromal cells. Blood, Apr 1;91(7), pp. 2387-2396.

Lagneaux, L., Delforge, A., De Bruyn, C., Bernier, M., \& Bron, D. (1999). Adhesion to bone marrow stroma inhibits apoptosis of chronic lymphocytic leukemia cells. Leukemia Lymphoma, Nov;35(5-6), pp. 445-453.

le Coutre, P., Tassi, E., Varella-Garcia, M., Barni, R., Mologni, L., Cabrita, G., Marchesi, E., Supino, R., \& Gambacorti-Passerini, C. (2000). Induction of resistance to the Abelson inhibitor STI571 in human leukemic cells through gene amplification. Blood, Mar 1;95(5), pp. 1758-1766.

Leslie, N.R., O'Prey, J., Bartholomew, C., \& Harrison, P.R. (1998). An activating mutation in the kit receptor abolishes the stroma requirement for growth of ELM erythroleukemia cells, but does not prevent their differentiation in response to erythropoietin. Blood, Dec 15;92(12), pp. 4798-4807.

Levis, M., Allebach, J., Tse, K.F., Zheng, R., Baldwin, B.R., Smith, B.D., Jones-Bolin S., Ruggeri B., Dionne C.,\& Small D. (2002). A FLT3-targeted tyrosine kinase inhibitor is cytotoxic to leukemia cells in vitro and in vivo. Blood, Jun 1;99(11), pp. 3885-3891. 
Levis, M., Pham, R., Smith, B.D., \& Small, D. (2004). In vitro studies of a FLT3 inhibitor combined with chemotherapy: sequence of administration is important to achieve synergistic cytotoxic effects. Blood, Aug 15;104(4), pp. 1145-1150.

Lierman, E., Lahortiga, I., Van Miegroet, H., Mentens, N., Marynen, P., \& Cools, J. (2007). The ability of sorafenib to inhibit oncogenic PDGFRbeta and FLT3 mutants and overcome resistance to other small molecule inhibitors. Haematologica, Jan;92(1), pp. 27-34.

Liesveld, J.L., Harbol, A.W., \& Abboud, C.N. (1996). Stem cell factor and stromal cell coculture prevent apoptosis in a subculture of the megakaryoblastic cell line, UT-7. Leuk Res, Jul;20(7), pp. 591-600.

Litwin, C., Leong, K.G., Zapf, R., Sutherland, H., Naiman, S.C., \& Karsan, A. (2002). Role of the microenvironment in promoting angiogenesis in acute myeloid leukemia. Am J Hematol, May;70(1), pp. 22-30.

Liu, Y. \& Gray, N.S. (2006). Rational design of inhibitors that bind to inactive kinase conformations. Nat Chem Biol. Jul;2(7), pp. 358-64.

Liu, W.M., Stimson, L.A., \& Joel, S.P. (2002). The in vitro activity of the tyrosine kinase inhibitor STI571 in BCR-ABL positive chronic myeloid leukaemia cells: synergistic interactions with anti-leukaemic agents. Br J Cancer, May 6;86(9), pp. 1472-8.

Liu, Z., Sun, C., Olejniczak E.T.,Meadows R.P., Betz S.F., Oost T., Herrmann J., Wu J.C., \& Fesik S.W. (2000). Structural basis for binding of Smac/DIABLO to the XIAP BIR3 domain. Nature, Dec 21-28;408(6815), pp. 1004-8.

Lockton, J.A., Smethurst, D., Macpherson, M., Tootell, R., Marshall, A.L., Clack, G., \& Gallagher, N.J. (2005). Phase I ascending single and multiple dose studies to assess the safety, tolerability and pharmacokinetics of AZD0530, a highly selective, dualspecific SRC-ABL inhibitor. J Clin Oncol ASCO Ann Meet Proc, 23(16S), Part I of II (June 1 Supplement), 3125a.

Lopes de Menezes, D.E., Peng, J., Garrett, E.N., Louie, S.G., Lee, S.H., Wiesmann, M., Tang, Y., Shephard, L., Goldbeck, C., Oei, Y., Ye H., Aukerman, S.L., \& Heise, C. (2005). CHIR-258: A potent inhibitor of FLT3 kinase in experimental tumor xenograft models of human acute myelogenous leukemia. Clin Cancer Res, July 15;11(14), pp. 5281-5291.

Lyman, S.D., Seaberg, M., Hanna, R., Zappone, J., Brasel, K., Abkowitz, J.L., Prchal, J.T., Schultz, J.C., \& Shahidi, N.T. (1995). Plasma/serum levels of flt3 ligand are low in normal individuals and highly elevated in patients with Fanconi anemia and acquired aplastic anemia. Blood, Dec 1;86(11), pp. 4091-4096.

Mahon, F. X., Deininger, M.W., Schultheis, B., Chabrol, J., Reiffers, J., Goldman, J.M., \& Melo, J.V. (2000). Selection and characterization of BCR-ABL positive cell lines with differential sensitivity to the tyrosine kinase inhibitor STI571: diverse mechanisms of resistance. Blood, Aug 1;96(3), pp. 1070-1079.

Manley, P. W., Cowan-Jacob, S.W., Buchdunger, E., Fabbro, D., Fendrich, G., Furet, P., Meyer, T., \& Zimmermann, J. (2002). Imatinib: a selective tyrosine kinase inhibitor. Eur J Cancer, Sep;38(Suppl 5), pp. S19-S27.

Mattison, R.J., Ostler, K.R., Locke, F.L., \& Godley, L.A. (2007). Implications of FLT3 mutations in the therapy of acute myeloid leukemia. Rev Recent Clin Trials, May;2(2), pp. 135-141.

Metzelder, S., Wang, Y, Wollmer, E., Wanzel, M., Teichler, S., Chaturvedi, A., Eilers, M., Enghofer, E., Neubauer, A., \& Burchert, A. (2009). Compassionate use of sorafenib 
in FLT3-ITDpositive acute myeloid leukemia: sustained regression before and after allogeneic stem cell transplantation. Blood, Jun 25;113(26), pp. 6567-6571.

Michor, F., Hughes, T.P., Iwasa, Y., Branford, S., Shah, N.P., Sawyers, C.L., \& Nowak, M.A. (2005). Dynamics of chronic myeloid leukemia. Nature, June 30;435(7046), pp. 12671270. PMID: 15988530

Mohi, M.G., Boulton, C., Gu, T.L., Sternberg, D.W., Neuberg, D., Griffin, J.D., Gilliland, D.G., \& Neel, B.G. (2004). Combination of rapamycin and protein tyrosine kinase (PTK) inhibitors for the treatment of leukemias caused by oncogenic PTKs. Proc Natl Acad Sci USA, Mar 2;101(9), pp. 3130-3135.

Mollgard, L., Deneberg, S., Nahi, H., Bengtzen, S., Jonsson-Videsater, K., Fioretos, T., Andersson, A., Paul C., \& Lehmann, S. (2008). The FLT3 inhibitor PKC412 in combination with cytostatic drugs in vitro in acute myeloid leukemia. Cancer Chemother Pharmacol, Aug;62(3), pp. 439-448.

Mony, U., Jawad, M., Seedhouse, C., Russell, N., \& Pallis, M. (2008). Resistance to FLT3 inhibition in an in vitro model of primary AML cells with a stem cell phenotype in a defined microenvironment. Leukemia, Jul;22(7), pp. 1395-1401.

Nagar, B., Bornmann, W.G., Pellicena, P., Schindler, T., Veach, D.R., Miller, W.T., Clarkson, B., \& Kuriyan, J. (2002). Crystal structures of the kinase domain of c-Abl in complex with the small molecule inhibitors PD173955 and imatinib (STI-571). Cancer Res, Aug 1;62(15), pp. 4236-4243.

Nakao, M., Yokota, S., Iwai, T., Kaneko, H., Horiike, S., Kashima, K., Sonoda, Y., Fujimoto, T., \& Misawa, S. (1996). Internal tandem duplication of the FLT3 gene found in acute myeloid leukemia. Leukemia, Dec;10(12), pp. 1911-1918.

Nelson, E.A., Walker, S.R., Weisberg, E., Bar-Natan, M., Barrett, R., Gashin, L.B., Terrell, S., Klitgaard, J.L., Santo, L., Addorio, M.R., Ebert, B.L., Griffin, J.D., \& Frank, D.A. (2011). The STAT5 inhibitor pimozide decreases survival of chronic myelogenous leukemia cells resistant to kinase inhibitors. Blood, Mar 24;117(12), pp. 3421-9.

Nishioka, C., Ikezoe, T., Yang, J., Takeuchi, S., Koeffler, H.P., \& Yokoyama, A. (2008a). MS275, a novel histone deacetylase inhibitor with selectivity against HDAC1, induces degradation of FLT3 via inhibition of chaperone function of heat shock protein 90 in AML cells. Leuk Res, Sept;32(9), pp. 1382-1392.

Nishioka, C., Ikezoe, T., Yang, J., Takeshita, A., Taniguchi, A., Komatsu, N., Togitani, K., Koeffler, H.P., \& Yokoyama, A. (2008b). Blockade of MEK/ERK signaling enhances sunitinib-induced growth inhibition and apoptosis of leukemia cells possessing activating mutations of the FLT3 gene. Leuk Res, Jun;32(6), pp. 865-872.

O’Farrell, A.M., Abrams, T.J., Yuen, H.A., Ngai, T.J., Louie, S.G., Yee, K.W., Wong, L.M., Hong, W., Lee, L.B., Town, A., Smolich, B.D., Manning, W.C., Murray, L.J., Heinrich, M.C., \& Cherrington, J.M. (2003a). SU11248 is a novel FLT3 tyrosine kinase inhibitor with potent activity in vitro and in vivo. Blood, May 1;101(9), pp. 3597-3605.

O'Farrell, A.M., Foran, J.M., Fiedler, W., Serve, H., Paquette, R.L., Cooper, M.A., Yuen, H.A., Louie, S.G., Kim, H., Nicholas, S., Heinrich, M.C., Berdel, W.E., Bello, C., Jacobs, M., Scigalla, P., Manning, W.C., Kelsey, S., \& Cherrington, J.M. (2003b). An innovative Phase I clinical study demonstrates inhibition of FLT3 phosphorylation by SU11248 in acute myeloid leukemia patients. Clin Cancer Res, Nov 15;9(15), pp. 5465-5476.

O'Farrell, A.M., Yuen, H.A., Smolich, B., Hannah, A.L., Louie, S.G., Hong, W., Stopeck, A.T., Silverman, L.R., Lancet, J.E., Karp, J.E., Albitar, M., Cherrington, J.M., \& Giles, F.J. 
(2004). Effects of SU5416, a small molecule tyrosine kinase receptor inhibitor, on FLT3 expression and phosphorylation in patients with refractory acute myeloid leukemia. Leuk Res, Jul;28(7), pp. 679-689.

O'Hare, T., Walters, D.K., Stoffregen, E.P., Sherbenou, D.W., Heinrich, M.C., Deininger, M.W., \& Druker, B.J. (2005). Combined Abl inhibitor therapy for minimizing drug resistance in chronic myeloid leukemia: Src/Abl inhibitors are compatible with imatinib. Clin Cancer Res, Oct 1;11(19 Pt 1), pp. 6987-6993.

O'Prey, J., Leslie, N., Itoh, K., Ostertag, W., Bartholomew, C., \& Harrison, P.R. (1998). Both stroma and stem cell factor maintain long-term growth of ELM erythroleukemia cells, but only stroma prevents erythroid differentiation in response to erythropoietin and interleukin-3. Blood, Mar 1;91(5), pp. 1548-1555.

Pluk, H., Dorey, K., \& Superti-Furga, G. (2002). Autoinhibition of c-ABL. Cell, Jan 25;108(2), pp. 247-259.

Pratz, K. \& Levis, M. (2008). Incorporating FLT3 inhibitors into acute myeloid leukemia treatment regimens. Leuk Lymphoma May;49(5), pp. 852-863.

Pratz, K.W., Cortes, J., Roboz, G.J., Rao, N., Arowojolu, O., Stine, A., Shiotsu, Y., Shudo, A., Akinaga, S., Small, D., Karp, J.E., \& Levis, M. (2009). A pharmacodynamic study of the FLT3 inhibitor KW-2449 yields insight into the basis for clinical response. Blood, Apr 23;113(17), pp. 3938-3946.

Pratz, K., Sato, T., Murphy, K.M., Stine, A., Rajkhowa, T., \& Levis, M. (2010). FLT3-mutant allelic burden and clinical status are predictive of response to FLT3 inhibitors in AML. Blood, Feb 18;115(7), pp. 1425-32.

Puttini, M., Coluccia, A.M., Boschelli, F., Cleris, L., Marchesi, E., Donella-Deana, A., Ahmed, S., Redaelli, S., Piazza, R., Magistroni, V., Andreoni, F., Scapozza, L., Formelli, F., \& Gambacorti-Passerini, C. (2006). In vitro and in vivo activity of SKI-606, a novel Src$\mathrm{Abl}$ inhibitor, against imatinib resistant Bcr-Abl+ neoplastic cells. Cancer Res, Dec 1;66(23), pp. 11314-11322.

Ray, A., Cowan-Jacob, S.W., Manley, PW, Mestan, J, \& Griffin, JD. (2007). Identification of BCR-ABL point mutations conferring resistance to the $\mathrm{Abl}$ kinase inhibitor AMN107 (nilotinib) by a random mutagenesis study. Blood, Jun 1;109(11), pp. 5011-5015.

Rafii, S., Mohle, R., Shapiro, F., Frey, B.M., \& Moore, M.A. (1997). Regulation of hematopoiesis by microvascular endothelium. Leuk Lymphoma, Nov;27(5-6), pp. 375-386.

Recher, C., Beyne-Rauzy, O., Demur, C., Chicanne, G., Dos Santos, C., Mas, V.M., Benzaquen, D., Laurent, G., Huguet, F., \& Payrastre, B. (2005). Antileukemic activity of rapamycin in acute myeloid leukemia. Blood, Mar 15;105(6), pp. 25272534.

Reindl, C., Bagrintseva, K., Vempati, S., Schnittger, S., Ellwart, J.W., Wenig, K., Hopfner, K.P., Hiddemann, W., \& Spiekermann K. (2006). Point mutations in the juxtamembrane domain of FLT3 define a new class of activating mutations in AML. Blood, May 1;107(9), pp. 3700-3707.

Rocnik, J.L., Okabe, R., Yu, J.C., Lee, B.H., Giese, N., Schenkein, D.P., \& Gilliland, D.G. (2006). Roles of tyrosine 589 and 591 in STAT5 activation and transformation mediated by FLT3-ITD. Blood, Aug 15;108(4), pp. 1339-1345.

Roche-Lestienne, C., Soenen-Cornu, V., Grardel-Duflos, N., Lai, J.L., Philippe, N., Facon, T., Fenaux, P., \& Preidhomme, C. (2002). Several types of mutations of the ABL gene 
can be found in chronic myeloid leukemia patients resistant to STI571, and they can pre-exist to the onset of treatment. Blood, Aug 1;100(3), pp. 1014-1018.

Roeder, I., Horn, M., Glauche, I., Hochhaus, A., Mueller, M.C., \& Loeffler, M. (2006). Dynamic modeling of imatinib-treated chronic myeloid leukemia: functional insights and clinical implications. Nature Med, Oct;12(10), pp. 1181-1184.

Rombouts, W.J., Blokland, I., Lowenberg, B., \& Ploemacher, R.E. (2000). Biological characteristics and prognosis of adult acute myeloid leukemia with internal tandem duplications in the FLT3 gene. Leukemia, Apr;14(4), pp. 675-683.

Rourmiantsev, S., Shah, N.P., Gorre, M.E., Nicoll, J., Brasher, B.B., Sawyers, C.L., \& Van Etten, R.A. (2002). Clinical resistance to the kinase inhibitor STI-571 in chronic myeloid leukemia by mutation of Tyr-253 in the ABL kinase domain P-loop. Proc. Natl Acad. Sci. USA, Aug 6;99(16), pp. 10700-10705.

Saglio, G., Kim, D.W., Issaragrisil, S., le Coutre, P., Etienne, G., Lobo, C., Pasquini, R., Clark, R.E., Hochhaus, A., Hughes, T.P., Gallagher, N., Hoenekopp, A., Dong, M., Haque, A., Larson, R.A., \& Kantarjian, H.M.; ENESTnd Investigators. (2010) Nilotinib versus imatinib for newly diagnosed chronic myeloid leukemia. $N$ Engl J Med, June 17;362(24), pp. 2251-2259.

Schindler, T., Bornmann, W., Pellicena, P., Miller, W.T., Clarkson, B., \& Kuriyan, J. (2000). Structural mechanism for STI-571 inhibition of Abelson tyrosine kinase. Science, Sep 15;289(5486), pp. 1938-1942.

Shah, N. P., Nicoll, J.M., Nagar, B., Gorre, M.E., Paquette, R.L., Kuriyan, J., \& Sawyers C.L. (2002). Multiple BCR-ABL kinase domain mutations confer polyclonal resistance to the tyrosine kinase inhibitor imatinib (STI571) in chronic phase and blast crisis chronic myeloid leukemia. Cancer Cell, Aug;2(2), pp. 117-125.

Shah, N.P., Tran, C., Lee, F.Y., Chen, P., Norris, D., \& Sawyers, C.L. (2004). Overriding imatinib resistance with a novel ABL kinase inhibitor. Science, Jun 16;305(5682), pp. 399-401.

Shaked, Y., Cervi, D., Neuman, M., Chen, L., Klement, G., Michaud, C.R., Haeri, M., Pak, B.J., Kerbel, R.S., \& Ben-David, Y. (2005). The splenic microenvironment is a source of proangiogenesis/inflammatory mediators accelerating the expansion of murine erythroleukemic cells. Blood, Jun 1;105(11), pp. 4500-4507.

Shankar, D.B., Li, J., Tapang, P., Owen, J., Pease, L.J., Dai, Y., Wei, R.Q., Albert, D.H., Bouska, J.J., Osterling, D.J., Guo, J., Marcotte, P.A., Johnson, E.F., Soni, N., Hartandi, K., Michaelides, M.R., Davidsen, S.K., Priceman, S.J., Chang, J.C., Rhodes, K., Shah, N., Moore, T.B., Sakamoto K.M., \& Glaser K.B. (2007). ABT-869, a multitargeted receptor tyrosine kinase inhibitor: inhibition of FLT3 phosphorylation and signaling in acute myeloid leukemia. Blood, Apr 15;109(8), pp. 3400-3408.

Shih, C.C., Hu, M.C., Hu, J., Medeiros, J., \& Forman, S.J. (1999). Long-term ex vivo maintenance and expansion of transplantable human hematopoietic stem cells. Blood, Sept 1;94(5), pp. 1623-36.

Shiotsu, Y., Kiyoi, H., Ishikawa, Y., Tanizaki, R., Shimizu, M., Umehara, H., Ishii, K., Mori, Y., Ozeki, K., Minami, Y., Abe, A., Maeda, H., Akiyama, T., Kanda, Y., Sato, Y., Akinaga, S., \& Naoe, T. (2009). KW-2449, a novel multikinase inhibitor, suppresses the growth of leukemia cells with FLT3 mutations or T315I-mutated BCR/ABL translocation. Blood, Aug 20;114(8), pp. 1607-1617. 
Smith, B.D., Levis, M., Beran, M., Giles, F., Kantarjian, H., Berg, K., Murphy, K.M., Dauses, T., Allebach, J., \& Small, D. (2004). Single-agent CEP-701, a novel FLT3 inhibitor, shows biologic and clinical activity in patients with relapsed or refractory acute myeloid leukemia. Blood, May 15;103(10), pp. 3669-3676.

Soverini, S., Martinelli, G., Rosti, G., Bassi, S., Amabile, M., Poerio, A., Giannini, B., Trabacchi, E., Castagnetti, F., Testoni, N., Luatti, S., de Vivo, A., Cilloni, D., Izzo, B., Fava, M., Abruzzese, E., Alberti, D., Pane, F., Saglio, G., \& Baccarani, M. (2005). ABL mutations in late chronic phase chronic myeloid leukemia patients with up-front cytogenetic resistance to imatinib are associated with a greater likelihood of progression to blast crisis and shorter survival: a study by the GIMEMA Working Party on Chronic Myeloid Leukemia. J. Clin. Oncol, Jun 20;23(18), pp. 4100-4109.

Stirewalt, D.L. \& Radich, J.P. (2003). The role of FLT3 in hematopoietic malignancies. Nat Rev Cancer Sep;3(9), pp. 650-65.

Stolzel, F., Steudel, C., Oelschlagel, U., Mohr, B., Koch, S., Ehninger, G., \& Thiede, C. (2010). Mechanisms of resistance against FLT3ITD positive human acute myeloid leukemia cells. Ann Hematol, Jul;89(7), pp. 653-662.

Stone, R.M., De Angelo, J., Galinsky, I., Estey, E., Klimek, V., Grandin, W., Lebwohl, D., Yap, A., Cohen, P., Fox, E., Neuberg, D., Clark, J., Gilliland, D.G., \& Griffin, J.D. (2004). Ann Hematol, 83(Suppl 1), pp. S89-90.

Strasser, A. (2005). The role of BH3-only proteins in the immune system. Nat Rev Immunol, Mar;5(3), pp. 189-200. PMID: 15719025

Tabe, Y., Jin, L., Tsutsumi-Ishii, Y., Xu, Y., McQueen, T., Priebe, W., Mills, G.B., Ohsaka, A., Nagaoka, I., Andreeff, M., \& Konopleva, M. (2007). Activation of integrin-linked kinase is a critical prosurvival pathway induced in leukemic cells by bone marrowderived stromal cells. Cancer Research, Jan 15;67(2), pp. 684-694.

Talpaz, M., Shah, N.P., Kantarjian, H., Donato, N., Nicoll, J., Paquette, R., Cortes, J., O'Brien, S., Nicaise, C., Bleickardt, E., Blackwood-Chirchir, M.A., Lyer, V., Chen, T.T., Huang, F., Decillis, A.P., \& Sawyers, C.L. (2006). Dasatinib in imatinib-resistant Philadelphia chromosome-positive leukemias. N Eng J Med, Jun 15;354(24), pp. 2531-2541.

Verfaillie, CM. (1993). Soluble factor(s) produced by human bone marrow stroma increase cytokine-induced proliferation and maturation of primitive hematopoietic progenitors while preventing their terminal differentiation. Blood, Oct 1;82(7), pp. 2045-53.

Von Bubnoff, N., Schneller, F., Peschel, C. \& Duyster, J. (2002). BCR-ABL gene mutations in relation to clinical resistance of Philadelphia-chromosome-positive leukaemia to STI571: a prospective study. Lancet, Feb 9;359(9305), pp. 487-491.

Von Bubnoff, N., Manley, P.W., Mestan, J., Sanger, J., Peschel, C., \& Duyster, J. (2006). BCR$\mathrm{ABL}$ resistance screening predicts a limited spectrum of point mutations to be associated with clinical resistance to the Abl kinase inhibitor nilotinib (AMN107). Blood, Aug 15;108(4), pp. 1328-1333.

Von Bubnoff, N., Engh, R.A., Aberg, E., Sanger, J., Peschel, C., \& Duyster, J. (2009). FMS-like tyrosine kinase 3-internal tandem duplication tyrosine kinase inhibitors display a nonoverlapping profile of resistance mutations in vitro. Cancer Res, Apr 1;69(7), pp. 3032-3041. 
Weisberg, E. \& Griffin, J.D. (2000). Mechanism of resistance to the ABL tyrosine kinase inhibitor STI571 in BCR/ABL-transformed hematopoietic cell lines. Blood, Jun 1;95(11), pp. 3498-505.

Weisberg, E., Manley, P.W., Breitenstein, W., Brüggen, J., Cowan-Jacob, S.W., Ray, A., Huntly, B., Fabbro, D., Fendrich, G., Hall-Meyers, E., Kung, A.L., Mestan, J., Daley, G.Q., Callahan, L., Catley, L., Cavazza, C., Azam, M., Neuberg, D., Wright, R.D., Gilliland, D.G., \& Griffin, J.D. (2005). Characterization of AMN107, a selective inhibitor of native and mutant Bcr-Abl. Cancer Cell, Feb;7(2):129-41. Erratum in: Cancer Cell. 2005 Apr;7(4), pp. 399. Mohammed, Azam [corrected to Azam, Mohammad].

Weisberg, E., Catley, L., Wright, R.D., Moreno, D., Banerji, L., Ray, A., Manley, P.W., Mestan, J.,

Fabbro, D., Jiang, J., Hall-Meyers, E., Callahan, L., DellaGatta, J.L., Kung, A.L., \& Griffin, J.D. (2007a). Beneficial effects of combining nilotinib and imatinib in preclinical models of BCR-ABL+ leukemias. Blood, Mar 1;109(5), pp. 2112-20.

Weisberg E., Wright R.D., Jiang J., Ray A., Moreno D., Manley P.W., Fabbro D., Hall-Meyers E., Catley L., Podar K., Kung A.L., \& Griffin J.D. (2006). Effects of midostaurin, nilotinib, and imatinib against GIST-associated PDGFRA mutants with differential imatinib sensitivity. Gastroenterology, Dec;131(6), pp. 1734-42.

Weisberg, E., Boulton, C., Kelly, L.M., Manley, P., Fabbro, D., Meyer, T., Gilliland, D.G., \& Griffin, J.D. (2002). Inhibition of mutant FLT3 receptors in leukemia cells by the small molecule tyrosine kinase inhibitor midostaurin. Cancer Cell, Jun;1(5), pp. 43343.

Weisberg, E., Banerji, L., Wright, R.D., Barrett, R., Ray, A., Moreno, D., Catley, L., Jiang, J., Hall-Meyers, E., Sauveur-Michel, M., Stone, R., Galinsky, I., Fox, E., Kung, A.L., \& Griffin, J.D. (2008a). Potentiation of antileukemic therapies by the dual PI3K/PDK1 inhibitor, BAG956: effects on BCR-ABL- and mutant FLT3-expressing cells. Blood, Apr 1;111(7), pp. 3723-34.

Weisberg, E., Roesel, J., Bold, G., Furet, P., Jiang, J., Cools, J., Wright, R.D., Nelson, E., Barrett, R., Ray, A., Moreno, D., Hall-Meyers, E., Stone, R., Galinsky, I., Fox, E., Gilliland, G., Daley, J.F., Lazo-Kallanian, S., Kung, A.L., \& Griffin, J.D. (2008b). Antileukemic effects of the novel, mutant FLT3 inhibitor NVP-AST487: effects on PKC412-sensitive and -resistant FLT3-expressing cells. Blood, Dec 15;112(13), pp. 5161-70.

Weisberg, E., Kung, A.L., Wright, R.D., Moreno, D., Catley, L., Ray, A., Zawel, L., Tran, M., Cools, J., Gilliland, G., Mitsiades, C., McMillin, D.W., Jiang, J., Hall-Meyers, E.,\& Griffin, J.D. (2007b). Potentiation of antileukemic therapies by Smac mimetic, LBW242: effects on mutant FLT3-expressing cells. Mol Cancer Ther, Jul;6(7), pp. 1951-61.

Weisberg, E., Wright, R.D., McMillin, D.W., Mitsiades, C., Ray, A., Barrett, R., Adamia, S., Stone, R., Galinsky, I., Kung, A.L., \& Griffin, J.D. (2008c). Stromal-mediated protection of tyrosine kinase inhibitor-treated BCR-ABL-expressing leukemia cells. Mol Cancer Ther, May;7(5), pp. 1121-9.

Weisberg, E., Barrett, R., Liu, Q., Stone, R., Gray, N., \& Griffin, J.D. (2009). FLT3 inhibition and mechanisms of drug resistance in mutant FLT3-positive AML. Drug Resist Updat, Jun;12(3), pp. 81-9. 
Weisberg, E., Choi, H.G., Ray, A., Barrett, R., Zhang, J., Sim, T., Zhou, W., Seeliger, M., Cameron, M., Azam, M., Fletcher, J.A., Debiec-Rychter, M., Mayeda, M., Moreno, D., Kung, A.L., Janne, P.A., Khosravi-Far, R., Melo, J.V., Manley, P.W., Adamia, S., Wu, C., Gray, N., \& Griffin, J.D. (2010a). Discovery of a small-molecule type II inhibitor of wild-type and gatekeeper mutants of BCR-ABL, PDGFRalpha, Kit, and Src kinases: novel type II inhibitor of gatekeeper mutants. Blood, May 27;115(21), pp. 4206-16.

Weisberg, E., Choi , H.G., Barrett, R., Zhou, W., Zhang, J., Ray, A., Nelson, E.A., Jiang, J., Moreno, D., Stone, R., Galinsky, I., Fox, E., Adamia, S., Kung, A.L., Gray, N.S., \& Griffin, J.D. (2010b). Discovery and characterization of novel mutant FLT3 kinase inhibitors. Mol Cancer Ther, Sep;9(9), pp. 2468-77.

Weisberg, E., Deng, X., Choi, H.G., Barrett, R., Adamia, S., Ray, A., Moreno, D., Kung, A.L., Gray, N., \& Griffin, J.D. (2010c). Beneficial effects of combining a type II ATP competitive inhibitor with an allosteric competitive inhibitor of BCR-ABL for the treatment of imatinib-sensitive and imatinib-resistant CML. Leukemia, Jul;24(7), pp. 1375-8.

Weisberg, E., Ray, A., Barrett, R., Nelson, E., Christie, A.L., Porter, D., Straub, C., Zawel, L., Daley, J.F., Lazo-Kallanian, S., Stone, R., Galinsky, I., Frank, D., Kung, A.L., \& Griffin, J.D. (2010d). Smac mimetics: implications for enhancement of targeted therapies in leukemia. Leukemia, Dec;24(12), pp. 2100-9.

White, D.L., Saunders, V.A., Dang, P., Engler, J., Zannettino, A.C., Cambareri, A.C., Quinn, S.R., Manley, P.W., \& Hughes, T.P. (2006). Oct-1 mediated influx is a key determinant of the intracellular uptake of imatinib but not nilotinib (AMN107): reduced OCT-1 activity is the cause of low in vitro sensitivity to imatinib. Blood, July 15;108(2), pp. 697-704.

White, D.L., Saunders, V.A., Quinn, S.R., Manley, P.W.,\& Hughes, T.P. (2007). Imatinib increases the intracellular concentration of nilotinib, which may explain the observed synergy between these drugs. Blood, Apr 15;109(8), pp. 3609-10.

Wu, G., Chai, J., Suber, T.L., Wu, J.W., Du, C., Wang, X., \& Shi, Y. (2000). Structural basis of IAP recognition by Smac/DIABLO. Nature, Dec 21-28;408(6815), pp. 1008-12.

Wodnar-Filipowicz, A., Lyman, S.D., Gratwohl, A., Tichelli, A., Speck, B., \& Nissen, C. (1996). Flt3 ligand level reflects hematopoietic progenitor cell function in aplastic anemia and chemotherapy-induced bone marrow aplasia. Blood, Dec 15;88(12), pp. 4493-4499.

Wu, J., Meng, F., Kong, L.Y., Peng, Z., Ying, Y., Bornmann, W.G., Darnay, B.G., Lamothe, B., Sun, H., Talpaz, M., \& Donato, N.J. (2008). Association between imatinib-resistant BCR-ABL mutation-negative leukemia and persistent activation of LYN kinase. $J$ Natl Cancer Inst, Jul 2;100(13), pp. 926-39.

Yamamoto, Y., Kiyoi, H., Nakano, Y., Suzuki, R., Kodera, Y., Miyawaki, S., Asou, N., Kuriyama, K., Yagasaki, F., Shimazaki, C., Akiyama, H., Saito, K., Nishimura, M., Motoji, T., Shinagawa, K., Takeshita, A., Saito, H., Ueda, R., Ohno, R., \& Naoe, T. (2001). Activating mutation of D835 within the activation loop of FLT3 in human hematologic malignancies. Blood, Apr 15;97(8), pp. 2434-2439.

Yee, K.W., O'Farrell, A.M., Smolich, B.D., Cherrington, J.M., McMahon, G., Wait, C.L., McGreevey, L.S., Griffith, D.J., \& Heinrich, M.C. (2002). SU5416 and SU5614 inhibit kinase activity of wild-type and mutant FLT3 receptor tyrosine kinase. Blood, Oct 15;100(8), pp. 2941-2949. 
Yee, K.W., Schittenheim, M., O'Farrell, A.M., Town, A.R., McGreevey, L., Bainbridge, T., Cherrington, J.M., \& Heinrich, M.C. (2004). Synergistic effect of SU11248 with cytarabine or daunorubicin on FLT3-ITD-positive leukemic cells. Blood, Dec 15;104(13), pp. 4202-4209.

Zarrinkar, P.P., Gunawardane, R.N., Cramer, M.D., Gardner, M.F., Brigham, D., Belli, B., Karaman, M.W., Pratz, K.W., Pallares, G., Chao, Q., Sprankle, K.G., Patel, H.K., Levis, M., Armstrong, R.C., James, J.,\& Bhagwat, S.S. (2009). AC220 is a uniquely potent and selective inhibitor of FLT3 for the treatment of acute myeloid leukemia (AML). Blood, Oct 1;114(14), pp. 2984-2992.

Zeng, Z., Samudio, I.J., Munsell, M., An, J., Huang, Z., Estey, E., Andreeff, M., \& Konopleva, M. (2006). Inhibition of CXCR4 with the novel RCP168 peptide overcomes stromamediated chemoresistance in chronic and acute leukemias. Mol Cancer Ther, Dec;5(12), pp. 3113-21.

Zhang, W., Konopleva, M., Shi, Y.X., McQueen, T., Harris, D., Ling, X., Estrov, Z., QuintasCardama, A., Small, D., Cortes, J., Andreeff, M. (2008). Mutant FLT3: a direct target of sorafenib in acute myelogenous leukemia. J Natl Cancer Inst, Feb 6;100(3), pp. 184-198.

Zhang, J., Adrian, F.J., Jahnke, W., Cowan-Jacob, S.W., Li, A.G., Iacob, R.E., Sim, T., Powers, J., Dierks, C., Sun, F., Guo, G.R., Ding, Q., Okram, B., Choi, Y., Woiciechowski, A., Deng, X., Liu, G., Fendrich, G., Strauss, A., Vaipai, N., Grzesiek, S., Tuntland, T., Liu, Y., Bursulava, B., Azam, M., Manley, P.W., Engen, J.R., Daley, G.Q., Warmuth, M., \& Gray, N.S. (2010). Targeting Bcr-Abl by combining allosteric with ATPbinding-site inhibitors. Nature, Jan 28;463(7280), pp. 501-506.

Zhou, J., Bi C., Janakakumara, J.V., Liu, S.C., Chng, W.J., Tay, K.G., Poon, L.F., Xie, Z., Palaniyandi, S., Yu, H., Glaser, K.B., Albert, D.H., Davidsen, S.K., \& Chen, C.S. (2009). Enhanced activation of STAT pathways and overexpression of survivin confer resistance to FLT3 inhibitors and could be therapeutic targets in AML. Blood, Apr 23;113(17), pp. 4052-4062.

Zwierzina, H., Anderson, J.E., Rollinger-Holzinger, I., Torok-Storb, B., Nuessler, V., \& Lyman, S.D. (1999). Endogenous FLT-3 ligand serum levels are associated with disease stage in patients with myelodysplastic syndromes. Leukemia, Apr;13(4), pp. 553-557. 


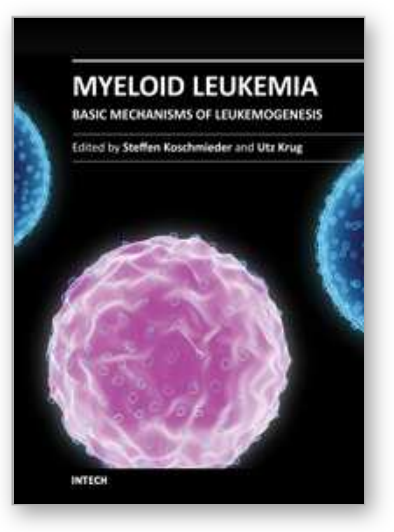

\author{
Myeloid Leukemia - Basic Mechanisms of Leukemogenesis \\ Edited by Dr Steffen Koschmieder
}

ISBN 978-953-307-789-5

Hard cover, 484 pages

Publisher InTech

Published online 14, December, 2011

Published in print edition December, 2011

The current book comprises a series of chapters from experts in the field of myeloid cell biology and myeloid leukemia pathogenesis. It is meant to provide reviews about current knowledge in the area of basic science of acute $(A M L)$ and chronic myeloid leukemia $(C M L)$ as well as original publications covering specific aspects of these important diseases. Covering the specifics of leukemia biology and pathogenesis by authors from different parts of the World, including America, Europe, Africa, and Asia, this book provides a colorful view on research activities in this field around the globe.

\title{
How to reference
}

In order to correctly reference this scholarly work, feel free to copy and paste the following:

Ellen Weisberg and James D. Griffin (2011). Causative Factors Involved in Development of Resistance to Tyrosine Kinase Inhibition and Novel Strategies Designed to Override This Resistance, Myeloid Leukemia Basic Mechanisms of Leukemogenesis, Dr Steffen Koschmieder (Ed.), ISBN: 978-953-307-789-5, InTech, Available from: http://www.intechopen.com/books/myeloid-leukemia-basic-mechanisms-ofleukemogenesis/causative-factors-involved-in-development-of-resistance-to-tyrosine-kinase-inhibition-andnovel-stra

\section{INTECH}

open science | open minds

\section{InTech Europe}

University Campus STeP Ri Slavka Krautzeka 83/A

51000 Rijeka, Croatia Phone: +385 (51) 770447

Fax: +385 (51) 686166

www.intechopen.com

\section{InTech China}

Unit 405, Office Block, Hotel Equatorial Shanghai

No.65, Yan An Road (West), Shanghai, 200040, China

中国上海市延安西路65号上海国际贵都大饭店办公楼 405 单元

Phone: +86-21-62489820

Fax: +86-21-62489821 
(C) 2011 The Author(s). Licensee IntechOpen. This is an open access article distributed under the terms of the Creative Commons Attribution 3.0 License, which permits unrestricted use, distribution, and reproduction in any medium, provided the original work is properly cited. 